\title{
Design for Safety Implementation Among Design Professionals in Construction: The Context of Palestine
}

DOI:

10.1016/j.ssci.2020.104742

Document Version

Accepted author manuscript

Link to publication record in Manchester Research Explorer

\section{Citation for published version (APA):}

Abueisheh, Q., Manu, P., Mahamadu, A. M., \& Cheung, C. (2020). Design for Safety Implementation Among Design Professionals in Construction: The Context of Palestine. Safety Science.

https://doi.org/10.1016/j.ssci.2020.104742

\section{Published in:}

Safety Science

\section{Citing this paper}

Please note that where the full-text provided on Manchester Research Explorer is the Author Accepted Manuscript or Proof version this may differ from the final Published version. If citing, it is advised that you check and use the publisher's definitive version.

\section{General rights}

Copyright and moral rights for the publications made accessible in the Research Explorer are retained by the authors and/or other copyright owners and it is a condition of accessing publications that users recognise and abide by the legal requirements associated with these rights.

\section{Takedown policy}

If you believe that this document breaches copyright please refer to the University of Manchester's Takedown Procedures [http://man.ac.uk/04Y6Bo] or contact uml.scholarlycommunications@manchester.ac.uk providing relevant details, so we can investigate your claim.

\section{OPEN ACCESS}




\title{
SAFETY SCIENCE
}

\section{Design for Safety Implementation Among Design Professionals in Construction: The Context of Palestine}

\author{
Accepted: 26 March 2020
}

Qusai Abueisheh $^{1}$, Patrick Manu ${ }^{1 *}$, Abdul-Majeed Mahamadu ${ }^{2}$ and Clara Cheung ${ }^{1}$

${ }^{1}$ Department of Mechanical, Aerospace and Civil Engineering, The University of Manchester, Manchester, United Kingdom.

${ }^{2}$ Faculty of Environment and Technology, University of the West of England, Bristol, United Kingdom.

* Corresponding author

Email: Patrick.Manu@manchester.ac.uk

Telephone: 00441613067572

Declarations of interest

None 


\begin{abstract}
Design for safety (DfS), also known as prevention through design, is a prominent means for tackling work-related illnesses and injuries in construction. However, the available DfS studies in construction have paid very limited attention to developing countries. Consequently, there is limited insight into DfS implementation in many developing countries including Palestine. This study therefore investigates DfS implementation among design professionals in the Palestinian construction industry. A questionnaire survey was used to obtain data from design professionals and the data was analysed using inferential statistics (i.e. analysis of variance and t-test) and descriptive statistics. The results revealed that the extent of engagement in DfS practices among the design professionals is very low despite a high awareness and positive attitude towards the concept of DfS. Additionally, while there is a great interest in undertaking DfS training, the designers' participation in training is low. Additionally, awareness of DfS, DfS education and training, professional body affiliation, level of education, years of experience, and size of organisation were found to have limited association with the extent of engagement in DfS practices by the designers. These findings suggest the presence of DfS implementation barriers/challenges, which are undermining the implementation of DfS by the design professionals in Palestine. Collaborative efforts are required by the construction industry stakeholders to improve DfS implementation. Furthermore, the findings mirror the outcomes of similar studies in other developing countries and thus highlight an urgent need for additional studies within developing countries to ascertain the barriers/challenges to DfS implementation in those geographic contexts.
\end{abstract}

Keywords: construction; design for safety; developing countries; Palestine; survey.

\title{
1. Introduction
}

The construction industry is considered as a major sector that contributes to the socio-economic development of nations. The importance of this sector lies in its role in providing the essential foundations for industrial production and its considerable contribution to job creation and to gross domestic product (GDP) (Hendrickson, 2008; Mahamid, 2012). In Palestine, which consists of two geographically separated areas (i.e. the West Bank and the Gaza Strip), the construction sector has been acting as a leading sector for driving the economic growth during the last 50 years (Fanack, 2017). In 2017, the construction sector contributed to around 6.5\% of the Palestinian GDP with about US \$942 million value added by this sector (Arab Monetary Fund [AMF], 2017). Furthermore, in 2010, the construction sector employed about 98,000 workers, which represents $17 \%$ of the total Palestinian workforce (Palestinian Central Bureau of Statistics [PCBS], 2011).

Despite the importance of the construction sector, it has been established that the construction sector is responsible for one of the highest rates of work-related fatalities, injuries, and illnesses around the world (Huang and Hinze, 2006; Atkinson and Westall, 2010; Manu et al., 2019). While occupational accidents are common in the construction industry around the world, the situation is dire in developing countries compared with developed countries (Takala et al., 2014). For instance, in the United Kingdom (UK), one of the developed countries (World Bank, 2019), 38 work related fatalities and 58,000 injuries were reported in the construction sector in 2017/2018 (Health and Safety Executive [HSE], 2018a). In Palestine, which is considered as a developing country (United Nations, 2018; World Bank, 2019), the construction industry is responsible for the highest work-related fatalities (Al-Sari' and Al-Khatib, 2012; Sawa, 2018). 
In 2018, The Ministry of Labour in Palestine reported 17 fatalities and 2,948 injuries in the construction industry in the West Bank only (Sawa, 2018). Considering the relatively small population of the West Bank of 2.98 million (PCBS, 2019) and its construction workforce size of 98,000 (PCBS, 2011), the construction fatalities in the Palestinian construction industry is high. This is particularly significant when compared to, for instance, the UK, which has a construction workforce of about 1.3 million (Office for National Statistics, 2018) and recorded 38 fatalities recorded in 2017/2018 (HSE, 2018a).

Many studies have shown that design decisions have a significant impact on workers' safety (Behm, 2005; Gibb et al, 2006). This evidenced contribution of design decisions to construction accidents has therefore given rise to the concept of "Design for Safety (DfS)", which entails anticipating and eliminating or mitigating potential occupational health and safety hazards associated with a building or structure during its design (Schulte et al., 2008). In the construction sector, the implementation of the concept of DfS has become an important mechanism to reduce occupational injuries and illnesses.

While the vast majority of DfS studies have focused on developed countries, there is a research gap regarding DfS studies in developing countries (Manu et al., 2018a, 2019), and especially in Palestine (Al-Sari' and Al-Khatib, 2012) because the literature on health and safety in Palestine reveals that there has been very limited study on DfS implementation in the construction industry. Consequently, the level of DfS knowledge and awareness, as well as the extent of its implementation among designers, are unknown. Meanwhile, $73 \%$ of work-related accidents or injuries were reported in the construction industry in Palestine in 2017 (Sawa, 2018). This knowledge gap amidst the poor status of health and safety in Palestine could hinder the industry and the government authorities from developing effective measures to improve the dire accident record in construction. Against this backdrop, this study investigates the implementation of DfS concept among design professionals in the construction industry in Palestine.

In the following sections, the status of construction sector' safety and health and DfS literature are presented. This is followed by underscoring the research gap regarding DfS research in Palestine. The research strategy adopted for the study is then outlined and subsequently, results of data analyses, discussion, and conclusions are presented.

\section{Status of Construction Sector Occupational Safety and Health (OSH) in Palestine}

Despite the socio-economic importance of the construction sector, the sector is infamous for being responsible for an alarming number of occupational fatalities, injuries and illnesses around the world (Atkinson and Westall, 2010; Votano and Sunindijo, 2014; Manu et al., 2019). A study by Martínez Aires et al. (2016) showed that workers in the construction sector are more exposed than workers in other sectors to chemical and biological risks, as well as noise and temperature hazards. Even though safety performance in the construction industry has improved since the 1990s in several countries, the injury rate in this industry is still higher than that of all other industries in several countries (Votano and Sunindijo, 2014; Department of Occupational Health and Safety, 2015; Ministry of Manpower, 2015; Bureau of Labor Statistics, 2018; HSE, 2019). For instance, the number of occupational fatal injuries in the UK construction industry has continuously been larger than that of all other industries in the past five years (HSE, 2019). Similarly, the United States of America (USA) construction industry employed 4.2\% of the total workforce in 2016 (Data USA, 2019; Department of Labor and Training, 2019), yet it accounted for around 19\% of total occupational fatalities (Bureau of 
Labor Statistics, 2018). Besides the social implications of occupational illnesses, injuries and fatalities that affect families and societies, significant cost implications are also incurred. For instance, it is estimated that construction work-related injuries and illnesses in the UK cost about Great Britain Pound (GBP) £1,100,000,000 in 2016 (HSE, 2018b).

While occupational accidents are common in the construction industry around the world, in developing countries [described here as low-income and middle-income economies based on World Bank (2019) classification] the situation is worse compared with developed countries [described here as high-income economies based on World Bank (2019) classification] (Takala et al., 2014). In Palestine, as a developing country, $73 \%$ of work-related accidents/injuries were reported in the construction industry in 2017 (Sawa, 2018). Falling and excavation are the main causes of death among construction workers (Enshass and Aqaad, 2011). The first construction safety legislation in Palestine was enacted in 2000, under the name of "The Palestinian Labour Act no. 7". Despite the improvements in this law since its establishment, the absence of unified safety regulations and the prevailing culture of concealment has hindered an effective reduction of accident rates (Enshass and Aqaad, 2011; Al-Sari' and Al-Khatib, 2012; Abu-Arra and AlTurk, 2014). Many studies have been conducted in Palestine to provide an insight into the profile of OSH in the construction. For instance, the survey by Enshassi et al. (2013) showed that OSH performance was ranked last as an evaluation and selection criterion when choosing construction contractors. This low emphasis on OSH criterion indicates the low level of interest and seriousness regarding OSH within the Palestinian construction industry. Another study by Al-Sari' and Al-Khatib (2012) argued that the over-reliance of the Palestinian Authority on foreign aids, especially in the construction sector, has encouraged the government to give priority to the achievement of these projects to the limit that detrimentally affects the safety of the workers. This argument is in line with the findings by Ling et al. (2009) that pressurising the workers to finish the job quickly increases the probability of accidents occurrence. In view of the expected increase in global construction output by $85 \%$ by 2030 (Global Construction Perspectives and Oxford Economics, 2015), Manu et al. (2019) hinted that the existing poor construction $\mathrm{OSH}$ profile in developing countries might even deteriorate unless appropriate actions are implemented. Design for safety is one of such actions/mechanisms by which occupational accidents, injuries and illnesses can be mitigated in construction (Behm, 2005, Gibb et al., 2006).

\section{Design for Safety (DfS)}

Accident causation in construction is a complex process and a multi-faceted phenomenon (Suraji et al., 2001; Haslam et al., 2005; Rodrigues et al., 2015). Accident causation literature shows that two main broad factors contribute to the occurrence of construction accidents: proximal factors and distal factors (Abdelhamid and Everett, 2000; Suraji et al., 2001; Haslam et al., 2005; Manu et al., 2010; Cooke and Lingard, 2011; Rodrigues et al., 2015). Proximal factors, which are usually site-based, are factors that directly lead to accident causation (e.g. unsafe worker action). Distal factors, which usually emanate from the pre-construction stage, are factors that can lead to the introduction of the proximal factors in the construction process (e.g. client decisions/requirements) (Suraji et al., 2001; Manu et al., 2014; Rodrigues et al., 2015). Decisions made upstream from the construction site have a significant influence on safety downstream (i.e. during the construction phase). Research has shown that among these influential upstream decisions are decisions made regarding the design of a building/structure (Behm, 2005; Gambatese et al., 2005a; Cooke and Lingard, 2011; Karakhan, 2016; Tymvios and Gambatese, 2016a). For instance, Korman (2001) asserted that breakthrough interventions 
are required to reduce construction $\mathrm{OSH}$ issues, and thus suggested to involve and motivate architects and engineers to take part in the workers' OSH considerations.

Traditionally, design professionals were viewed to be solely responsible for the safety of the end-users of the facility being designed. Consequently, the occupational safety of workers in construction was attributed to the contractors (Hinze and Wiegand, 1992). However, there has been a paradigm shift as more recent studies have emphasised the contribution of design professionals to construction accident causation (Behm, 2005; Haslam et al., 2005; Tymvios and Gambatese, 2016a). For instance, Behm (2005) investigated 224 fatality cases; the results showed that $42 \%$ of the causalities were associated with design. Gibb et al. (2006) also studied 100 construction accidents and found that $50 \%$ of the accidents could have been mitigated with alternative design options. Another study by Behm (2006) reviewed 450 construction incidents and concluded that 151 incidents were related to design decisions. Furthermore, a more recent survey of 184 construction practitioners by Manu et al. (2014), showed that a complex design (i.e. design with intricate aesthetic qualities) has a higher potential to influence the occurrence of construction accidents than a simpler design. This evidenced contribution of design decisions to construction accidents has therefore given rise to the concept of "Design for Safety".

The concept of "Design for Safety (DfS)", also referred to as "prevention through design", "design risk management", "safe design" and "safety in design", has been gaining considerable momentum among researchers during the last three decades (Poghosyan et al., 2018). The concept of DfS involves designers "designing out" (i.e. eliminating or avoiding) and reducing hazards throughout the design phase in order to decrease the probability of accidents, injuries or illnesses to workers (Schulte et al., 2008). By adopting the concept of DfS, designers are able to take into account the OSH of construction workers while designing a facility (Toole and Gambatese, 2008). The concept of DfS is also aligned to the "hierarchy of control" which emphasise that eliminating or avoiding OSH hazards is a more effective means of preventing adverse OSH outcomes.

In addition to the evidenced contribution of DfS to workers' health and safety, the implementation of the concept of DfS can yield further benefits. For instance, Manuele (2009) affirms that the cost, effort and coordination required for addressing safety needs early in the project lifecycle are greatly fewer than those required later in adjusting the design to meet these needs (Manuele, 2009 cited in Tymvios and Gambatese, 2016a). This view is supported by the time-safety influence curve by Szymberski (1997), which demonstrates that the ability to address safety issues is greatest during the early stages of projects. Although the implementation of DfS could result in increased project initial costs, total project lifecycle costs are expected to be lower (Tymvios and Gambatese, 2016b). For instance, Toole (2005) suggests that the decrease in construction costs (due to the increased productivity and decreased workers' compensation costs when implementing DfS) outweighs any increase in the design costs. Moreover, Gambatese et al. (1997) affirmed that implementing DfS would eliminate many construction hazards, therefore, reduces the need for temporary safety measures during the construction phase, which in turn can reduce total project costs. Furthermore, the implementation of DfS could decrease maintenance costs by eliminating hazards that can affect maintenance workers (Gambatese et al., 1997; Toole et al., 2017). In a similar way, while implementing DfS could increase the duration of the design process due to the extra efforts needed (Toole et al., 2013), implementing DfS can decrease construction duration (Christianson, 2005; Karakhan, 2016; Tymvios and Gambatese, 2016b). This is because the implementation of DfS could improve workers' morale and increase productivity (Toole et al., 
2013), reduce work delays caused by workers' injuries (Toole et al., 2017), and decrease the need for using personal protective equipment (PPE) and safety measures, which usually impose some restrictions on the workers' movements and site accessibility (Gambatese et al., 2005b; Toole et al., 2017). Apart from the impact on projects' costs and durations, implementing DfS can also protect and enhance designers' reputation, and thus increase clients' recognition of their efforts (Tymvios and Gambatese, 2016b). Furthermore, workers can benefit from the reduced hazards and higher productivity, which can lead to higher wages (Christianson, 2005).

\subsection{Factors Affecting Design for Safety}

Within the construction industry, DfS research has highlighted factors that can affect the implementation of the concept of DfS (Poghosyan et al. 2018). These factors include designer attitude/acceptance of the concept; designer knowledge and education; DfS legislation; clients' influence; and DfS tools (Poghosyan et al. 2018). These factors are further discussed below.

\subsubsection{Designer attitude/acceptance}

DfS literature has shown that designers' attitude towards the concept of DfS constitutes a key factor that affects its implementation (Hinze and Wiegand, 1992; Gambatese et al., 2005a; Morrow et al., 2016). Designers' attitude implies that if designers do not accept the mitigation of OSH risk as a part of their design function, then they are less likely to implement the concept of DfS (Gambatese et al., 2005a). In their work, Morrow et al. (2016) affirmed that designers' attitude towards safety is influenced by their interpretation of the term OSH as well as their experience. Similarly, Öney-Yazıcı and Dulaimi (2015) noted that designers' nationalities, experience, age, and professional background influence their attitudes towards the concept of DfS. The designers' attitude towards safety can also vary depending on the aspect of design. For instance, Sacks et al. (2015) carried out a study to identify the aspects of design which designers are willing to change for safety considerations and the aspects which they are not. The findings showed that designers are less willing to change their designs if the change entails changing the appearance of the structure, and they responded that the appearance of their design outweighs any safety requirements. While the findings by Sacks et al. (2015) indicate that DfS requirements could limit the designer's creativity, these findings are not in line with the survey results by Öney-Yazıcı and Dulaimi (2015) in which designers stated that the implementation of DfS does not limit their creativity.

\subsubsection{Designer knowledge and education}

Although designers can hold a positive attitude towards the concept of DfS, the lack of DfS related knowledge and education can prevent them from implementing this concept (Gambatese and Hinze, 1999; Gambatese et al., 2005a). The DfS systematic literature review by Poghosyan et al. (2018) showed that about $60 \%$ of the journal articles on DfS that were examined $(n=164)$ had explored designers' knowledge and education. This focus of research reflects the significance of this factor on DfS implementation. Given that DfS involves integrating construction knowledge into the design process (Öney-Yazıc1 and Dulaimi, 2015), Gambatese and Hinze (1999) noted that the fragmented nature of the construction process prevents the construction knowledge to be transferred from the construction site to the designers. Thus, the designers' lack of understanding of construction processes and site hazards serves as a barrier to implementing the DfS concept (Weinstein et al., 2005; Öney-Yazıc1 and Dulaimi, 2015). As part of the efforts aimed to reduce this knowledge shortage, Toole (2005) suggested that engineering students should actively engage in construction sites to acquire construction knowledge. This suggestion is supported by the work of Hayne et al. (2017) which provides empirical evidence on the contribution of construction site experience in improving the designer's ability to identify construction hazards. Besides the importance of construction knowledge and site experience that has been widely acknowledged, López-Arquillos et al. 
(2015) emphasised the importance of formal education for designers in improving workplace safety. This was supported by the study of Behm et al. (2014), which showed that educational interventions effectively changed engineering students' perceptions of accident causality and safe design.

\subsubsection{Legislation}

Given the established linkage between construction accidents and design (Behm, 2005), many countries have introduced OSH laws, which require designers to consider $\mathrm{OSH}$ in the design of projects. DfS legislation have been prominent in the European Union (EU) due to the European Framework Directive 92/57/EEC which stipulates minimum safety and health requirements at temporary or mobile construction sites. The directive establishes a chain of responsibility linking construction project parties and it requires that occupational safety and health is taken into consideration during the design, planning and execution of construction works. Countries within the Union have transposed the provisions of the Directive into their national legislation (EUR-lex, 2020). The impact of DfS legislation on DfS implementation has been found to be varied. For instance, Martínez Aires et al. (2016) investigated the implementation of DfS regulations in Spain and in the UK, and found that implementation of DfS in the design phase in the UK is clearer since the regulations are explicit about designers obligations. They also found that DfS measures in Spain are mainly carried out to avoid legal fines rather than to reduce workplace accidents. Aside the DfS regulations in European countries (see Martínez Aires et al., 2010) other countries have also introduced similar regulations. Examples are the Workplace Safety and Health (Design for Safety) Regulations 2015 in Singapore, and the Work Health and Safety Acts and Regulations in Australia.

In the USA, many efforts to enact DfS regulations were rejected by design professionals due to the concerns about increased liability exposure (Hinze and Wiegand, 1992; Gambatese, 2000). Interestingly, a survey by Gambatese et al. (2005a) in the USA showed that the participants who expressed their concerns in enacting DfS legislation, due to the increased liability exposure, were rated as less knowledgeable and less accepting of the DfS concept than other participants. As part of the efforts to increase the acceptance of such legislation in the USA, Behm (2008) suggested adopting design-build project delivery method, where both the designer and the constructor fall under one contract, as this can eliminate the liability issue. Behm (2008) also suggested that the USA government should take the lead in DfS implementation by incorporating it as a requirement in government projects. Furthermore, Toole et al. (2013) noted that construction stakeholders must acknowledge that the implementation of the concept of DfS requires more time, tools and knowledge than the traditional practices, and thus any proposed legislation must include equitable compensation for the designer, to become more acceptable.

\subsubsection{Client's influence}

The importance of the client in promoting OSH requirements in construction projects has been widely recognised in the literature (Goh and Chua, 2016; Tymvios and Gambatese, 2016b; Toh et al., 2017). The level of influence held by the client in promoting these OSH considerations, including DfS, can vary depending on the existence or absence of DfS legislation (Toole et al., 2017). For instance, in the United Kingdom (UK), specific duties are shared between clients, designers and contractors under the Construction Design and Management (CDM) regulations (HSE, 2015a), and thus the influence of the client in promoting the concept of DfS is evident. However, the lack of legislative framework regarding DfS in the USA has increased the role of the client in promoting the concept of DfS (Tymvios and Gambatese, 2016b). 
Many studies have been conducted to identify the means by which clients can promote the concept of DfS. For instance, Gambatese et al. (2005a) discussed the importance of clients' acknowledgement of safety in order to place it as a high priority over other project criteria. They also discussed how clients can motivate designers to implement DfS through contractual requirements and monetary incentives. Toole et al. (2017) also discussed project delivery methods and recommended that clients can adopt alternative methods (e.g. design-build) to enable a collaborative approach between the contractor and the designer during the design stage, and thus better implementation of DfS. While the previous studies have focused on the methods by which clients can promote DfS, the work of Tymvios and Gambatese (2016b) has focused on the possible methods of motivating clients to implement DfS. They concluded that clients can be convinced to implement the concept of DfS by providing them with supporting evidence on the financial benefits of implementing DfS. In addition, Goh and Chua (2016) argued that clients' concern for reputation can be leveraged to motivate them to promote DfS.

\subsubsection{DfS tools, methods and standards}

Parallel to the growing interest in the concept of DfS during the last three decades, many research efforts have been made to develop various tools and methods to enable designers to implement the concept of DfS in their designs (Gambatese et al., 1997; Gangolells et al., 2010; Zhang et al., 2013). Such tools, which include computer-based databases, graphics and checklists, can help designers who have limited safety knowledge and construction experience to implement DfS concept (Toole, 2005). One of the earliest DfS computer-based tools, "Design for Construction Safety ToolBox," was developed by Gambatese et al. (1997). This tool identifies project-specific safety hazards and proposes alternative designs to eliminate or reduce these hazards. The advancements in computer-based technologies in the 2000s allowed the development of more sophisticated tools and methodologies to help designers in implementing DfS (Poghosyan et al., 2018). Examples of these are: a safety indicator developed by Sadeghi et al. (2015) to identify the presence of hazards during the earliest design phases; a methodology developed by Gangolells et al. (2010) to help designers in comparing overall safety risks of various construction designs; and, an automated safety rule checking using building information models (BIM) which identifies, during the design stage, any potential fall-related accidents and reports when, where, why, and what safety measures are needed to prevent these accidents (Zhang et al., 2013). Poghosyan et al. (2019) has also developed a web-based capability maturity tool to assist design firms to ascertain strengths and deficiencies in their capability to implement DfS in order to inform capability development.

\subsection{Towards Investigating Design for Safety in Construction industry in Palestine}

In reviewing construction OSH literature, a few studies within the context of Palestine (the West Bank \& the Gaza Strip) have been conducted which are worthy of consideration. These are summarised in Table 1 below. Table 1 demonstrates that, while some construction OSH studies have examined issues in Palestine, the vast majority have focused on the Gaza Strip. While both the West Bank and the Gaza Strip constitute the Palestinian Territories, the two regions are quite disparate areas due to the siege of the Gaza Strip since 2007 (Barakat et al., 2019). This implies that the findings of the studies in the Gaza Strip may not reflect the situation in the West Bank. The table also shows that most of these studies have focused on the views of clients, owners, and contractors regarding $\mathrm{OSH}$, while none investigated DfS implementation among designers. However, one study examined the linkage between the design phase and construction site accidents. The study by Al-Jubeh and Ziara (2012) on DfS investigated five existing buildings in the Gaza Strip based on the concept of DfS. The design of each building was analysed to determine how the design accounted for construction safety hazards. The study also emphasised the potential of the DfS concept in reducing accidents in 
the Palestinian construction sector. However, this study did not examine issues regarding DfS awareness, knowledge and practice among design professionals.

Table 1: Health and safety studies within the Palestinian construction industry

\begin{tabular}{|c|c|c|c|c|}
\hline Author & Study Focus & $\begin{array}{l}\text { Location } \\
\text { of Study }\end{array}$ & Method of study & Findings \\
\hline Enshassi (1997) & $\begin{array}{l}\text { Causes of accidents and } \\
\text { safety procedures used } \\
\text { by local contractors. }\end{array}$ & $\begin{array}{l}\text { The Gaza } \\
\text { Strip }\end{array}$ & $\begin{array}{l}\text { Thirty-five } \\
\text { questionnaires of } \\
\text { local contractors. }\end{array}$ & $\begin{array}{l}\text { The study highlighted the main } \\
\text { causes of construction accidents, } \\
\text { emphasised the need to introduce } \\
\text { OSH legislations, and noted the } \\
\text { importance of safety training. }\end{array}$ \\
\hline $\begin{array}{l}\text { Enshassi et al. } \\
\text { (2007) }\end{array}$ & $\begin{array}{l}\text { The perception of } \\
\text { owners, consultants, and } \\
\text { contractors towards } \\
\text { safety in construction in } \\
\text { the Gaza Strip. }\end{array}$ & $\begin{array}{l}\text { The Gaza } \\
\text { Strip }\end{array}$ & $\begin{array}{l}\text { Eighty-three } \\
\text { questionnaires of } \\
\text { contractors, owners } \\
\text { and consultants. }\end{array}$ & $\begin{array}{l}\text { The study investigated the main } \\
\text { causes of construction injuries } \\
\text { and fatalities (i.e. falling from } \\
\text { height, dropped objects and } \\
\text { materials, and being caught under } \\
\text { excavation). It also concluded that } \\
\text { the lack of safety knowledge, } \\
\text { safety training and carelessness of } \\
\text { workers are the main reasons for } \\
\text { construction accidents. }\end{array}$ \\
\hline $\begin{array}{l}\text { Enshassi et al. } \\
\text { (2008) }\end{array}$ & $\begin{array}{l}\text { Identify, evaluate, and } \\
\text { rank factors that } \\
\text { influence safety } \\
\text { performance of } \\
\text { subcontractors in the } \\
\text { Gaza Strip. }\end{array}$ & $\begin{array}{l}\text { The Gaza } \\
\text { Strip }\end{array}$ & $\begin{array}{l}\text { Literature review to } \\
\text { identify the factors } \\
\text { affecting the safety } \\
\text { performance of } \\
\text { subcontractors } \\
\text { followed by } 34 \\
\text { questionnaires of } \\
\text { subcontractors. }\end{array}$ & $\begin{array}{l}\text { The study underlined the } \\
\text { importance of providing safety } \\
\text { training courses for workers. It } \\
\text { also highlighted the effect of } \\
\text { complex and difficult } \\
\text { construction sites features (i.e. } \\
\text { poor soil) on safety performance. }\end{array}$ \\
\hline $\begin{array}{l}\text { Enshassi et al. } \\
(2009)\end{array}$ & $\begin{array}{l}\text { To identify the success } \\
\text { criteria and success } \\
\text { factors that affect } \\
\text { construction project } \\
\text { performance; and to } \\
\text { elicit perceptions of } \\
\text { their relative } \\
\text { importance. }\end{array}$ & $\begin{array}{l}\text { The Gaza } \\
\text { Strip }\end{array}$ & $\begin{array}{l}\text { Eighty-eight } \\
\text { questionnaires of } \\
\text { owners, consultants } \\
\text { and contractors. }\end{array}$ & $\begin{array}{l}\text { The study showed that 'health } \\
\text { and safety', as a success } \\
\text { criterion, was ranked 7th, 8th and } \\
\text { 8th (out of } 10 \text { criteria) by the } \\
\text { owners, consultants and } \\
\text { contractors, respectively. }\end{array}$ \\
\hline $\begin{array}{l}\text { Enshass and } \\
\text { Aqaad (2011) }\end{array}$ & $\begin{array}{l}\text { Assess the level of the } \\
\text { safety practices in } \\
\text { construction companies } \\
\text { in the Gaza Strip. }\end{array}$ & $\begin{array}{l}\text { The Gaza } \\
\text { Strip }\end{array}$ & $\begin{array}{l}\text { Fifty-one } \\
\text { questionnaires of } \\
\text { construction } \\
\text { companies. }\end{array}$ & $\begin{array}{l}\text { The study showed that most of the } \\
\text { construction companies lack } \\
\text { safety departments, manuals and } \\
\text { safety knowledge. }\end{array}$ \\
\hline $\begin{array}{l}\text { Al-Jubeh and } \\
\text { Ziara (2012) }\end{array}$ & $\begin{array}{l}\text { Assess the local } \\
\text { practices of construction } \\
\text { industry in Palestine } \\
\text { related to the DfS } \\
\text { approach. }\end{array}$ & $\begin{array}{l}\text { The Gaza } \\
\text { Strip }\end{array}$ & $\begin{array}{l}\text { Analysis of five } \\
\text { case study buildings } \\
\text { already constructed. }\end{array}$ & $\begin{array}{l}\text { The study reviewed five } \\
\text { constructed buildings and } \\
\text { investigated the level of } \\
\text { implementation of DfS in their } \\
\text { designs. }\end{array}$ \\
\hline $\begin{array}{l}\text { Al-Sari' and Al- } \\
\text { Khatib (2012) }\end{array}$ & $\begin{array}{l}\text { Assess worker's } \\
\text { experiences and } \\
\text { perceptions of safety at } \\
\text { construction sites. }\end{array}$ & $\begin{array}{l}\text { The } \\
\text { southern } \\
\text { West } \\
\text { Bank } \\
\end{array}$ & $\begin{array}{l}\text { Direct interviews } \\
\text { with } 349 \\
\text { construction } \\
\text { workers. }\end{array}$ & $\begin{array}{l}\text { The study noted the low level of } \\
\text { construction safety as a result of } \\
\text { lack of enforcement of safety } \\
\text { legislations. }\end{array}$ \\
\hline $\begin{array}{l}\text { Enshass et al. } \\
\text { (2013) }\end{array}$ & $\begin{array}{l}\text { Identify and rank the } \\
\text { significant factors } \\
\text { affecting safety } \\
\text { performance in the } \\
\text { Palestinian construction } \\
\text { industry. }\end{array}$ & $\begin{array}{l}\text { The Gaza } \\
\text { Strip }\end{array}$ & $\begin{array}{l}\text { Fifty-one } \\
\text { questionnaires of } \\
\text { contractors. }\end{array}$ & $\begin{array}{l}\text { The study identified the most } \\
\text { important factors which affect the } \\
\text { safety performance. The study } \\
\text { also emphasised the importance } \\
\text { of enforcing safety regulations. }\end{array}$ \\
\hline $\begin{array}{l}\text { Enshassi et al. } \\
\text { (2013) }\end{array}$ & $\begin{array}{l}\text { Investigate contractors' } \\
\text { evaluation and selection } \\
\text { criteria in the }\end{array}$ & $\begin{array}{l}\text { The Gaza } \\
\text { Strip }\end{array}$ & $\begin{array}{l}\text { Fifty-one } \\
\text { questionnaires of }\end{array}$ & $\begin{array}{l}\text { The study showed that OSH } \\
\text { performance of the contractor, as } \\
\text { an evaluation and selection }\end{array}$ \\
\hline
\end{tabular}




\begin{tabular}{l|l|l|l|l}
\hline & $\begin{array}{l}\text { Palestinian construction } \\
\text { industry. }\end{array}$ & & $\begin{array}{l}\text { public sector clients } \\
\text { and consulting } \\
\text { Firms. }\end{array}$ & $\begin{array}{l}\text { criterion, was ranked last among } \\
\text { the 13 factors. }\end{array}$ \\
\hline $\begin{array}{l}\text { Enshassi and Abu } \\
\text { Zaiter (2014) }\end{array}$ & $\begin{array}{l}\text { Investigate the } \\
\text { application of lean tools } \\
\text { and its effect on safety. }\end{array}$ & $\begin{array}{l}\text { The Gaza } \\
\text { Strip }\end{array}$ & $\begin{array}{l}\text { Thirty-one } \\
\text { questionnaires of } \\
\text { contractors and } \\
\text { clients. }\end{array}$ & $\begin{array}{l}\text { The study suggested lean tools as } \\
\text { a good means to improve } \\
\text { construction safety. It also } \\
\text { highlighted the lack of knowledge } \\
\text { and training as the major barriers } \\
\text { in using lean construction tools. }\end{array}$ \\
\hline $\begin{array}{l}\text { Enshassi et al. } \\
\text { (2016) }\end{array}$ & $\begin{array}{l}\text { Investigate safety- } \\
\text { related applications of } \\
\text { building information } \\
\text { modelling and building } \\
\text { information modelling } \\
\text { adoption barriers. }\end{array}$ & $\begin{array}{l}\text { The Gaza } \\
\text { Strip }\end{array}$ & $\begin{array}{l}\text { Thirty-seven } \\
\text { questionnaires of } \\
\text { clients, consultants } \\
\text { and contractors. }\end{array}$ & $\begin{array}{l}\text { The study highlighted the benefits } \\
\text { of using BIM based safety tools. } \\
\text { Itso suggested providing } \\
\text { training courses to increase BIM } \\
\text { implementation in the } \\
\text { construction sector. }\end{array}$ \\
\hline
\end{tabular}

Considering the established linkage between design and construction accidents, the poor performance of $\mathrm{OSH}$ in the Palestinian construction sector, and the very limited insight regarding DfS implementation in Palestine, there is need for research to examine DfS implementation issues in Palestine. It is on this premise that this research sought to investigate DfS implementation among design professionals in the Palestinian construction industry.

\section{Research Methods}

Aligned to the research's interest of getting a generic perspective of issues regarding DfS implementation among design professionals in Palestine, a quantitative research approach, particularly a cross-sectional questionnaire survey was adopted. While the survey approach is suitable in obtaining a generalised view of phenomenon (Bryman, 2012; Naoum, 2013; Creswell, 2014), it has also been used in similar DfS studies which examined DfS implementation among designers in other countries (see Goh and Chua, 2016; Manu et al., 2018a; 2019).

\subsection{Design of Survey Instrument}

The questionnaire was designed to constitute two main sections as follows.

Part 1: This section captured respondents' general information relating to their role, experience in construction, experience in their role, construction related education, professional affiliation, and information about their organisation.

Part 2: This section captured respondents' awareness, attitude, and practise of the concept of DfS. It also captured their DfS education and training as well as views regarding factors that influence DfS implementation.

- Regarding DfS awareness, the participants were required to indicate if they were aware of DfS concept before participating in the research.

- Regarding their attitude towards the DfS concept, the participants were requested to rate the importance of implementing this concept using a five-point Likert scale (i.e. $1=$ not important all; 2 = low importance; 3 = moderate importance; 4 = high importance; and $5=$ very high importance).

- Regarding implementation of DfS, the participants were required to identify their frequency of engagement in DfS practices (15 practices) using five-point Likert scale (i.e. $1=$ never; $2=$ rarely; $3=$ sometimes; $4=$ often; $5=$ always). The 15 practises, 
which are linked to the mitigation of major causes of work-related illnesses and injuries in the construction industry (e.g. manual handling, work at height, work in confined spaces, site congestion and exposure to substances hazardous to health) were adopted from previous DfS studies which inquired into DfS implementation among designers in other developing countries (Manu et al., 2018a, 2019).

- Regarding DfS education and training, the participants were asked to specify whether they have received DfS lessons and training and whether they are interested in receiving DfS training. They were also asked to indicate their preferred method of DfS training.

- Regarding the factors that affect the implementation of DfS (previously discussed in the literature), the participants were asked to assess the degree to which the factors influence the implementation of DfS. A five-point Likert scale (i.e. $1=$ Not at all; $2=$ Low; 3 = Moderate; 4 = High; 5 = Very high) was used.

Although design professionals (i.e. architects, civil and building engineers) in Palestine constituted the population, the survey was administered in the West Bank due to: the very limited coverage of OSH research in the West Bank; and accessibility difficulties to the Gaza Strip. While the focus of the study was therefore design professionals in the West Bank, there was the challenge of unavailability of a record/database of design professionals working in the West Bank. As a result it was not possible to ascertain the total number of design professionals in the West Bank. Hämäläinen et al. (2006) and Manu et al. (2018a, 2019) also confirmed a similar challenge in respect of obtaining required accessible information records for research, especially in developing countries. Due to the aforementioned challenge regarding obtaining a record/database of designers which could serve as a sampling frame, two techniques were used in this research in order to reach the potential respondents (Saunders et al., 2016). Firstly, snow ball sampling was used, in which initial prospective respondents were identified from the researchers' industry contacts and from the official website of the Engineers Association in the West Bank (2019). Prospective participants were then asked to forward the questionnaire to other design professionals within their professional network. Secondly, self-selection sampling technique was used whereby the questionnaire was posted on relevant online Palestinian construction professional group website. Regarding the first distribution technique to potential respondents, a total of 60 questionnaires were sent and 25 responses were received, resulting in a $41.6 \%$ response rate. Regarding the second distribution technique, as it is not possible to ascertain the number of people who received the online questionnaire, a response rate could not be calculated. Overall, from the questionnaire administration, 60 responses were received. The response size is comparable to the response sizes from other construction OSH surveys in Palestine (as shown in Table 1) and it is respectable when juxtaposed against the relatively small population and construction workforce size in Palestine (PCBS, 2011; 2019). While a higher number of responses was reported in other construction DfS studies [e.g. 130 responses were reported by Manu et al. (2018b) in a survey in Ghana and 161 responses were reported by Manu et al. (2019) in a survey in Nigeria], it is worth noting that the population of these countries [i.e. 30.5 million for Ghana and 200 million for Nigeria (World Population Review, 2019a; 2019b)] is significantly higher than the population of the West Bank (i.e. 2.98 million) (PCBS, 2019). Furthermore, other construction DfS studies reported a lower number of responses. For instance, a DfS survey in Singapore by Goh and Chua (2016) reported 43 responses. Based on the foregoing discussion, the number of collected responses in this study can be deemed to be reasonable.

\subsection{Data Analyses}

The obtained data was initially inputted into Microsoft Excel for screening and then exported to IBM Statistical Package for Social Sciences (SPSS) Statistics version 23. Descriptive 
statistical analyses (i.e. frequencies, means and standard deviations) and inferential statistical analyses (i.e. one-way analysis of variance (ANOVA), independent samples t-test and one sample t-test) were conducted.

Given the established linkage between design and construction OSH, this study considered that DfS should be an integral component of the design process. Subsequently, the expectation held by this research (in line with similar DfS studies in developing countries (Manu et al., 2018a, 2019) was that the level of designers' engagement in the DfS practices should be "often" at the least (if it is not "always"), especially considering that the examined 15 DfS practices are connected to the mitigation of major causes of construction illnesses and injuries. As the level of engagement in DfS practices was gauged by examining the frequency of participants' engagement in DfS practices (using a five-point Likert scale), the one sample t-test was conducted using 3.5 as the test value. The test value of 3.5 was used because 3.5 approximates to the nearest scale point of 4 , which is interpreted as "often" based on the scale descriptors. Thus, from the one-sample t-test, a practice with a mean frequency of engagement which is significantly greater than 3.5 can be deemed to be implemented at least often by designers. This approach of assessing level of designers' engagement in DfS practices was also applied in other DfS surveys (see Manu et al., 2018a, 2019).

The independent samples $t$-tests and ANOVA were useful in exploring differences in DfS implementation among various groups within the sample (Field, 2013). This was used to explore associations between respondents' characteristics (e.g. their DfS awareness, education, training, professional body membership, and work experience) and implementation of DfS. The exploration of the associations using one-way ANOVA and independent samples $t$-test was undertaken as previous DfS studies suggest that these items may affect DfS implementation (Gambatese et al., 2005a; Manu et al., 2018a; 2019). From the tests, outcomes with $p \leq 0.05$ are considered to be significant as recommended by Field (2013).

\section{Results}

This section presents the outcomes of the data analyses within the following sub-sections.

\subsection{Background information of participants}

Table 2 presents the background information of the research participants. The table shows that the majority (i.e. 50\%) of the participants are civil engineers. Concerning the highest level of education, the majority (i.e. 70\%) of the respondents have a bachelor's degree. The table also shows that the vast majority (i.e. 90\%) of the participants are affiliated to a professional association, which is the Palestinian Engineers Association. Regarding years of experience in role, Figure 1 shows that $60 \%$ of the participants have up to 5 years, $18 \%$ have between $6-10$ years, and $15 \%$ have more than 10 years. Regarding years of construction sector experience, Figure 1 shows that $50 \%$ of the participants have up to 5 years, $27 \%$ have between $6-10$ years, and $22 \%$ have over 10 years. The mean experience of participants in the construction sector and in their role are 8.36 years (standard deviation=8.78) and 6.2 years (standard deviation= 6.96), respectively. Figure 2 shows that the majority (i.e. 56\%) of the respondents work in micro firms (i.e. firms with 1-10 employees) and Figure 3 shows that half of the respondents work in architectural and engineering firms. 
Table 2: Background information of participants

\begin{tabular}{|c|l|l|}
\hline Demographic item & Frequency & Percentage \\
\hline $\begin{array}{c}\text { Professional Role } \\
\text { Architect }\end{array}$ & 23 & $38 \%$ \\
\hline Civil Engineer & 30 & $50 \%$ \\
\hline Building Engineer & 7 & $12 \%$ \\
\hline Highest level of education & & \\
\hline Bachelor's degree & 42 & $70 \%$ \\
\hline Master's degree & 13 & $22 \%$ \\
\hline PhD degree & 5 & $8 \%$ \\
\hline Professional body membership & 54 & $10 \%$ \\
\hline Yes & 6 & \\
\hline No & 5 & \\
\hline
\end{tabular}

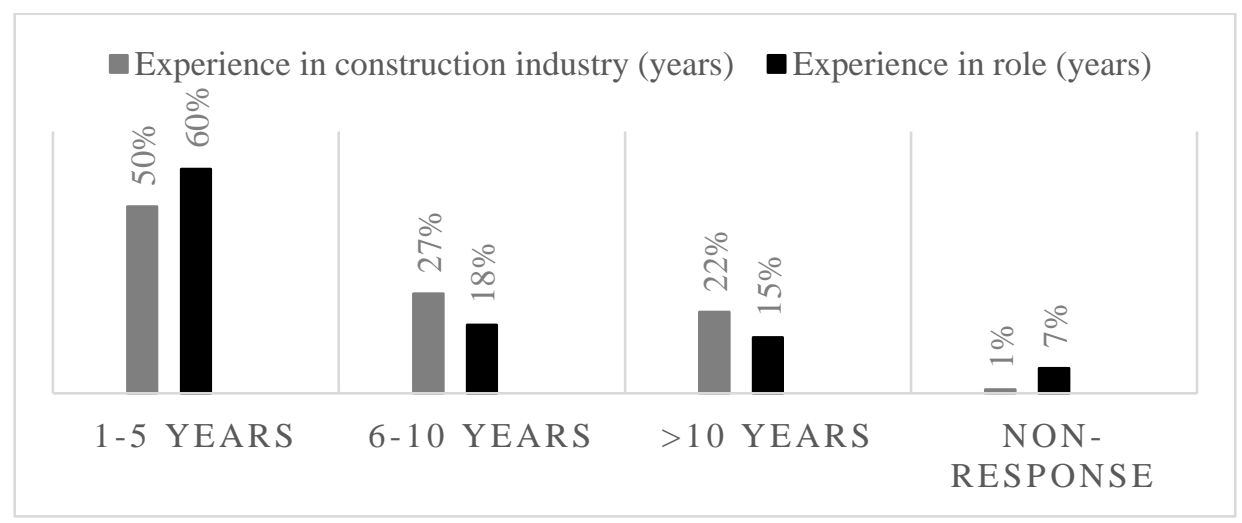

Figure 1: Respondents' experience 


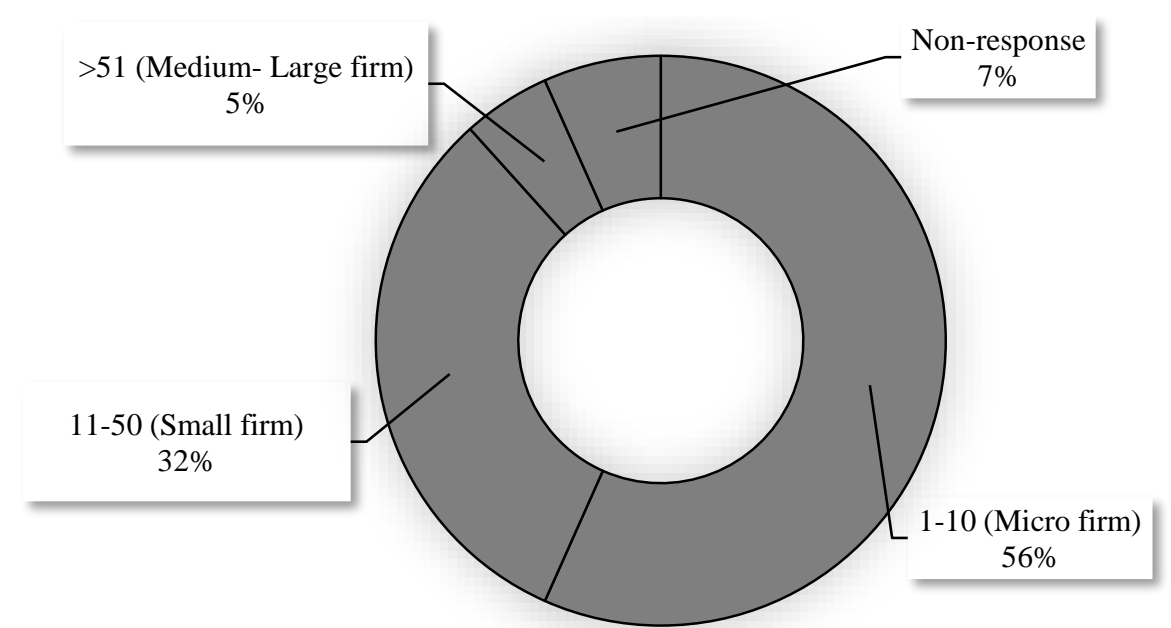

Figure 2: Size of the respondents' organisation

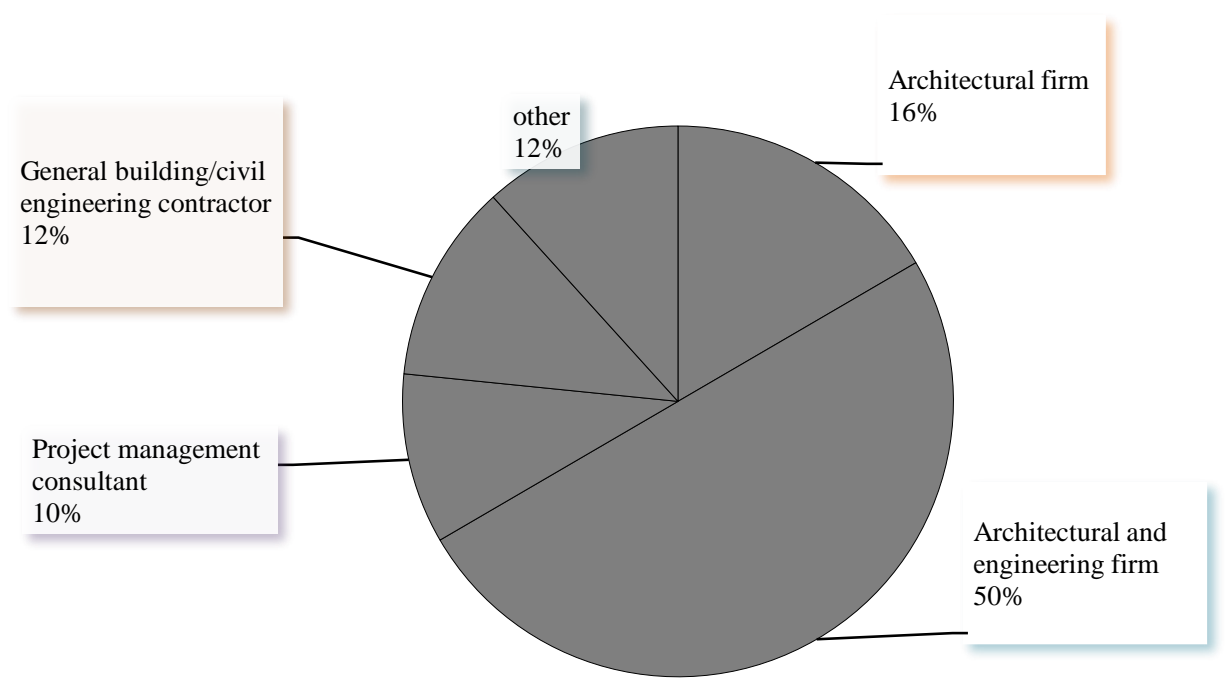

Figure 3: Type of the respondents' organisation

\subsection{Attitude towards DfS}

Figure 4 shows that most of the respondents (i.e. 82\%) consider the importance of implementing DfS to be "very high" or "high" and none considers it to be not important. A one sample $t$-test was undertaken to determine if the participants' attitude towards DfS is significantly higher than the test value of 3.5 (which approximates to 4 (i.e. "high importance" on the 5-point scale"). Table 3 shows that the mean of the respondents' attitude is significantly greater than 3.5. Therefore, the respondents generally consider the importance of DfS to be high.

Moreover, as shown in Figure 5, all the respondents (i.e. 100\%) indicated that they would include DfS in their work if given a choice. These results demonstrate a very positive attitude of the designers towards the concept of DfS. However, as shown by Figure 6, over half (i.e. $58 \%$ ) of the respondents are of the view that the Palestinian construction industry is not ready to take on the responsibility of DfS in projects. 
Table 3: One sample t-test for the importance of applying DfS

\begin{tabular}{|c|c|c|c|c|c|c|c|c|c|c|}
\hline \multirow[t]{3}{*}{ Item } & \multirow[t]{3}{*}{$\mathrm{n}$} & \multirow[t]{3}{*}{ Mean } & \multirow[t]{3}{*}{ Std. Dev. } & \multirow{3}{*}{$\begin{array}{l}\text { Std. } \\
\text { Error } \\
\text { Mean }\end{array}$} & \multicolumn{6}{|c|}{ Test Value $=3.5$} \\
\hline & & & & & \multirow[t]{2}{*}{$\mathrm{t}$} & \multirow[t]{2}{*}{$\mathrm{df}$} & \multirow[t]{2}{*}{$p$ (1-tailed) } & \multirow[t]{2}{*}{$\begin{array}{c}\text { Mean } \\
\text { Difference }\end{array}$} & \multicolumn{2}{|c|}{$\begin{array}{c}95 \% \\
\text { Confidence } \\
\text { Interval }\end{array}$} \\
\hline & & & & & & & & & Lower & Upper \\
\hline $\begin{array}{l}\text { Importance } \\
\text { of applying } \\
\text { DfS }\end{array}$ & 60 & 4.17 & 0.806 & 0.104 & 6.407 & 59 & 0.000 & 0.667 & 0.46 & 0.87 \\
\hline
\end{tabular}

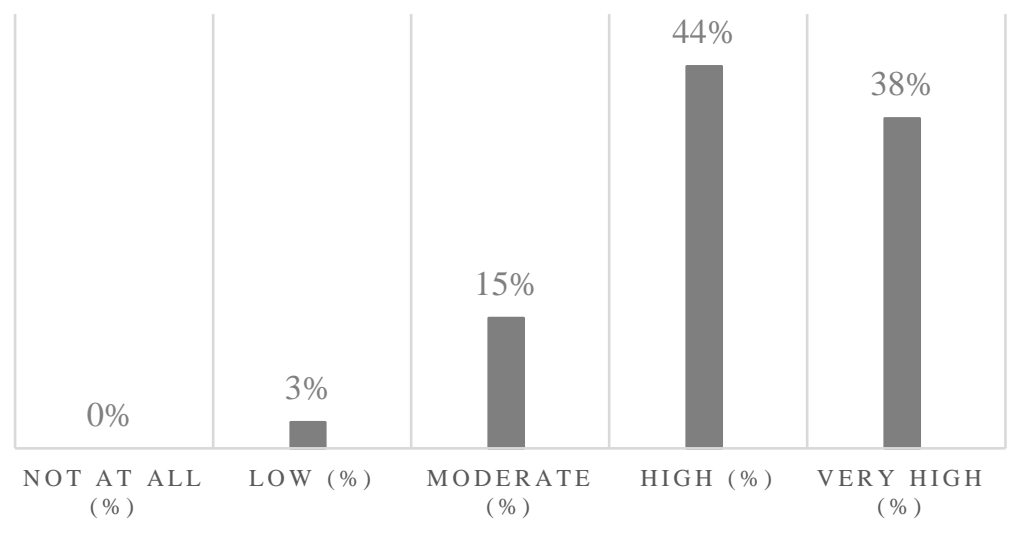

Figure 4: Importance of implementing DfS

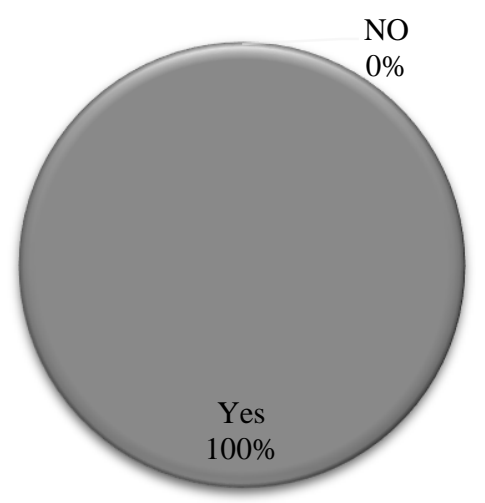

Figure 5: Attitude towards implementing DfS 


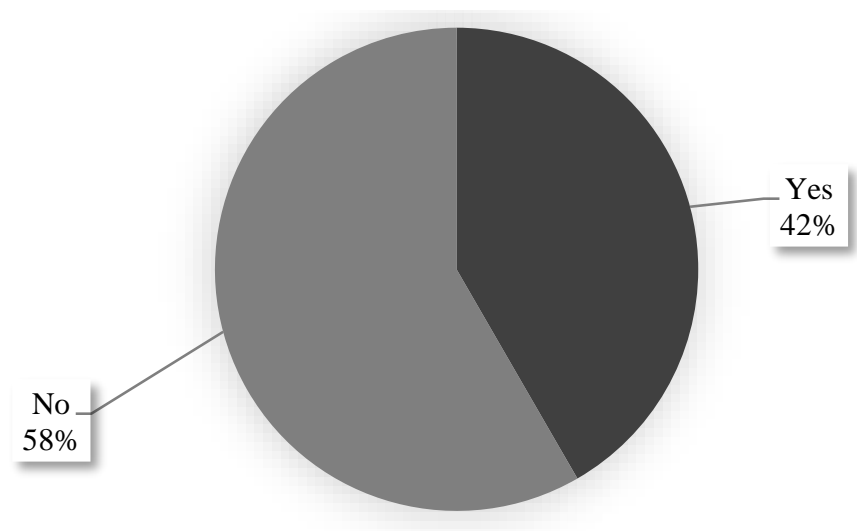

Figure 6: Readiness of the Palestinian construction industry for DfS implementation

\subsection{Awareness of DfS, DfS education and training}

As shown in Table 4, 70\% of the respondents are aware of DfS, even though only $30 \%$ of the respondents have received DfS lessons as part of formal education and only $18 \%$ have engaged in DfS training. The results also show that the majority of respondents (i.e. 90\%) indicated an interest in receiving DfS training. Of those who are interested in DfS training, the vast majority (i.e. $93 \%$ ) prefer attending seminar/workshop, and 33\% prefer online courses/study materials.

Table 4: Awareness of DfS, DfS education and training

\begin{tabular}{|c|c|c|}
\hline Item & Frequency & Percentage \\
\hline \multicolumn{3}{|l|}{ Participants who are aware of $D f S$} \\
\hline Aware & 42 & $70 \%$ \\
\hline Not aware & 18 & $30 \%$ \\
\hline \multicolumn{3}{|l|}{ Participants'DfS lessons } \\
\hline Received lessons & 18 & $30 \%$ \\
\hline Not received lessons & 42 & $70 \%$ \\
\hline \multicolumn{3}{|l|}{ Participants' DfS training } \\
\hline Have undertaken training & 11 & $18 \%$ \\
\hline Have not undertaken training & 49 & $82 \%$ \\
\hline \multicolumn{3}{|c|}{ Participants who are interested in engaging in DfS training } \\
\hline Interested participants & 54 & $90 \%$ \\
\hline Participants who are not interested & 6 & $10 \%$ \\
\hline \multicolumn{3}{|c|}{ a Participants' preference regarding methods of $D f S$ training } \\
\hline Online course/study materials & 18 & $33 \%$ \\
\hline Attending seminar/workshop & 50 & $93 \%$ \\
\hline
\end{tabular}

\subsection{Factors affecting DfS implementation}

Drawing from the review of literature on the factors that affect DfS implementation, six factors were given to the participants to rate the extent to which the factors influence the implementation of DfS. The six factors are:

- Availability of related computer tools to help designers to include DfS in their designs;

- Availability of DfS professional development training programmes;

- Availability of industry standards, codes or guides on DfS;

- Emphasis on DfS by the government; 
- Emphasis on DfS by the client; and

- Inclusion of DfS education in architecture and engineering courses at universities.

As shown in Figure 7, the inclusion of DfS education in architecture and engineering courses at universities was ranked to be the most important factor. One sample $t$-test was carried out to determine if the mean score of the importance of the DfS factors is significantly larger than 3.5 (i.e. the test value). Table 5 shows that the mean importance for all the factors is significantly greater than 3.5. Therefore, the respondents consider the influence of all the factors to be high.

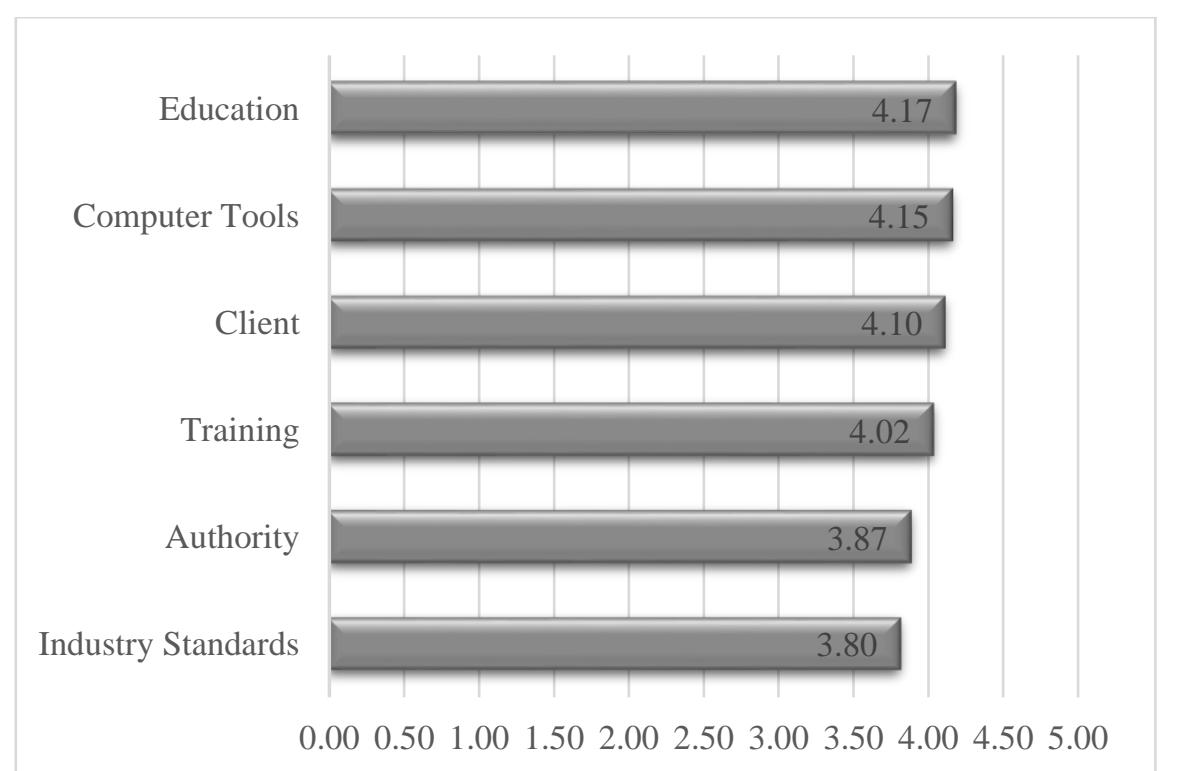

Figure 7: Average importance of factors that affect DfS implementation 
Table 5: One sample t-test for factors that affect the implementation of DfS

\begin{tabular}{|c|c|c|c|c|c|c|c|c|c|c|c|}
\hline \multirow{3}{*}{$\begin{array}{l}\text { Factors affecting } \\
\text { DfS }\end{array}$} & \multirow[t]{3}{*}{$\mathrm{n}$} & \multirow[t]{3}{*}{ Mean } & \multirow{3}{*}{$\begin{array}{l}\text { Rank of } \\
\text { Mean }\end{array}$} & \multirow[t]{3}{*}{ Std. Dev. } & \multirow{3}{*}{$\begin{array}{l}\text { Std. Error } \\
\text { Mean }\end{array}$} & \multicolumn{6}{|c|}{ Test Value $=3.5$} \\
\hline & & & & & & \multirow[t]{2}{*}{$\mathrm{t}$} & \multirow[t]{2}{*}{$\mathrm{df}$} & \multirow[t]{2}{*}{$\begin{array}{c}p(1- \\
\text { tailed })\end{array}$} & \multirow[t]{2}{*}{$\begin{array}{c}\text { Mean } \\
\text { Difference }\end{array}$} & \multicolumn{2}{|c|}{$\begin{array}{c}95 \% \\
\text { Confidence Interval } \\
\end{array}$} \\
\hline & & & & & & & & & & Lower & Upper \\
\hline Education & 60 & 4.17 & 1 & 0.960 & 0.124 & 5.381 & 59 & 0.000 & 0.667 & 0.42 & 0.91 \\
\hline Computer Tools & 60 & 4.15 & 2 & 0.777 & 0.100 & 6.477 & 59 & 0.000 & 0.650 & 0.45 & 0.85 \\
\hline Client & 60 & 4.10 & 3 & 0.817 & 0.105 & 5.687 & 59 & 0.000 & 0.600 & 0.39 & 0.81 \\
\hline Training & 59 & 4.02 & 4 & 0.919 & 0.120 & 4.321 & 58 & 0.000 & 0.517 & 0.28 & 0.76 \\
\hline Authority & 60 & 3.87 & 5 & 0.873 & 0.113 & 3.255 & 59 & 0.001 & 0.367 & 0.14 & 0.59 \\
\hline Industry Standards & 60 & 3.80 & 6 & 1.054 & 0.136 & 2.204 & 59 & 0.016 & 0.300 & 0.03 & 0.57 \\
\hline
\end{tabular}




\subsection{Engagement in DfS practices}

The level of engagement in DfS practices was gauged by examining the frequency of participants' engagement in the 15 practices.

Table 6: Participants' level of engagement in DfS practices

\begin{tabular}{|c|c|c|c|c|c|c|c|}
\hline \multirow{2}{*}{$\begin{array}{l}\text { DfS } \\
\text { practice } \\
\text { code }\end{array}$} & \multirow[t]{2}{*}{ DfS practice ${ }^{a}$} & \multicolumn{6}{|c|}{ Frequency of engagement in DfS practice } \\
\hline & & 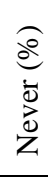 & 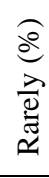 & 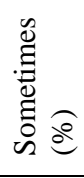 & $\underbrace{\frac{8}{0}}_{0}$ & 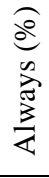 & 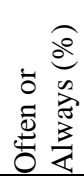 \\
\hline DfS-P.1 & $\begin{array}{l}\text { I design to avoid construction operations that create } \\
\text { hazardous fumes, vapour and dust (e.g. disturbance } \\
\text { of existing asbestos and cutting blockwork and } \\
\text { concrete). }\end{array}$ & 10 & 14 & 19 & 25 & 32 & 57 \\
\hline DfS-P.2 & $\begin{array}{l}\text { I specify materials that require less frequent } \\
\text { maintenance or replacement. }\end{array}$ & 3 & 12 & 19 & 49 & 17 & 66 \\
\hline DfS-P.3 & $\begin{array}{l}\text { I specify materials that are easier to handle such as } \\
\text { lightweight blocks. }\end{array}$ & 0 & 8 & 36 & 44 & 12 & 56 \\
\hline DfS-P.4 & $\begin{array}{l}\text { I design to take into account the safe movement of } \\
\text { site workers, plants, \& equipment on a project site } \\
\text { during construction. }\end{array}$ & 8 & 12 & 20 & 41 & 19 & 60 \\
\hline DfS-P.5 & $\begin{array}{l}\text { I specify materials that have less hazardous chemical } \\
\text { constituents. }\end{array}$ & 12 & 14 & 24 & 36 & 14 & 50 \\
\hline DfS-P.6 & $\begin{array}{l}\text { I eliminate materials that could create a significant } \\
\text { fire risk during construction. }\end{array}$ & 5 & 14 & 31 & 34 & 16 & 50 \\
\hline DfS-P.7 & $\begin{array}{l}\text { I design to position buildings/structures to minimise } \\
\text { risks from buried services and overhead cables. }\end{array}$ & 8 & 19 & 17 & 31 & 25 & 56 \\
\hline DfS-P.8 & $\begin{array}{l}\text { I design to mitigate the possible adverse impact a } \\
\text { project could have on the safe movement of the } \\
\text { general public during construction. }\end{array}$ & 5 & 17 & 22 & 34 & 22 & 56 \\
\hline DfS-P.9 & $\begin{array}{l}\text { I design elements (e.g. walls, floors, etc.) so that they } \\
\text { can be prefabricated offsite. }\end{array}$ & 39 & 47 & 7 & 7 & 0 & 7 \\
\hline DfS-P.10 & $\begin{array}{l}\text { I design to minimise or eliminate the need to work at } \\
\text { height. }\end{array}$ & 22 & 24 & 27 & 19 & 8 & 27 \\
\hline DfS-P.11 & $\begin{array}{l}\text { I design to minimise or eliminate the need for workers } \\
\text { to work in a confined space. }\end{array}$ & 8 & 15 & 34 & 31 & 12 & 43 \\
\hline DfS-P.12 & $\begin{array}{l}\text { I highlight unusual construction considerations that } \\
\text { have safety implications to the contractor such as } \\
\text { key sequence of erecting/construction. }\end{array}$ & 7 & 18 & 31 & 32 & 12 & 44 \\
\hline DfS-P.13 & $\begin{array}{l}\text { I follow a structured/systematic procedure for } \\
\text { undertaking design health and safety risk assessment } \\
\text { (e.g. using a tool, template, or form for design health } \\
\text { and safety risk assessment). }\end{array}$ & 22 & 37 & 17 & 17 & 7 & 24 \\
\hline DfS-P.14 & $\begin{array}{l}\text { I produce designs that enable ease of } \\
\text { building/constructing. }\end{array}$ & 0 & 7 & 28 & 48 & 17 & 65 \\
\hline DfS-P.15 & $\begin{array}{l}\text { I prepare hazard identification drawings which show } \\
\text { significant hazards that may not be obvious to a } \\
\text { contractor. }\end{array}$ & 39 & 26 & 19 & 14 & 2 & 16 \\
\hline
\end{tabular}

Note: ${ }^{a}$ The DfS practices adopted from Manu et al. (2018a, 2019).

From Table 6, for six out of the 15 practices, less than $50 \%$ of the respondents engage in them "often" or "always". Based on the aforementioned expectation that the level of designers' engagement in the DfS practices should be at least "often" (if not "always"), the one sample $t$ test was conducted to determine if the mean frequencies of implementing the DfS practices can be regarded as being at least "Often" (Manu et al., 2018a; 2019). Table 7 shows that only one out of the 15 practices can be regarded as being implemented at least "Often" by the 
participants, based on a $p$ (1-tailed) $\leq 0.05$. This practice is: producing designs that enable ease of building/constructing (i.e. DfS-P.14).

\subsubsection{Independent samples t-test results}

The independent samples $t$-tests were carried out in order to explore whether there are statistically significant differences in the mean of the frequency of engagement in the 15 DfS practices by the following clusters:

- Participants who are aware of DfS vs. participants who are not aware.

- Participants who are affiliated to a professional body vs. participants who are not.

- Participants who have received DfS lessons vs. participants who have not.

- Participants who have received DfS training vs. participants who have not.

The following are the results of the four tests. For conciseness, only the significant results (i.e. $p(2$-tailed $) \leq 0.05)$ are presented below and summarised in the Tables 8-10.

From the test, for five out of the 15 practices, a significant difference was obtained between the participants who are aware of DfS and those who are not aware (as shown in Table 8). These five practices are DfS-P.3, DfS-P.4, DfS-P.7, DfS-P.10 and DfS-P.13.

The results, presented in Table 9, show that for only one practice (i.e. DfS-P.15) a significant difference was obtained between the participants who are affiliated to a professional association and the participants who are not affiliated to a professional association.

Regarding the comparison between the participants who have received DfS lessons and participants who have not received DfS lessons, a significant difference was obtained for five out of the 15 DfS practices (as shown in Table 10). These five practices are DfS-P.3, DfS-P.4, DfS-P.8, DfS-P.9 and DfS-P.15.

Regarding the comparison between the participants who have undertaken DfS training and participants who have not undertaken training, there were no significant outcomes. The result for only one practice (i.e. DfS-P.13) was near to being significant as follows: participants who have received DfS training $(\mathrm{M}=3.09, \mathrm{SD}=1.375)$; participants who have not received DfS training $(\mathrm{M}=2.35, \mathrm{SD}=1.139) ; \mathrm{t}=1.862, p(2$-tailed $)=0.068$.

\subsubsection{ANOVA results}

One-way ANOVA tests were carried out to explore whether there are statistically significant differences in the mean of the frequency of engagement in the 15 DfS practices by four clusters:

- Professional role (grouped as architects; civil engineers; and building engineers).

- The highest level of education (grouped as bachelor's degree; master's degree; and $\mathrm{PhD}$ ).

- Years of experience in role (grouped as 1-5; 6-10; and over 10).

- The size of the organisation by number of employees (grouped as 1-10; 11-50; and over 50 employees).

The following are the results of the one-way ANOVA tests. Once again for conciseness only the significant results (i.e. $p(2$-tailed) $\leq 0.05)$ are discussed below and summarised in the Tables 11-13. 
Table 7: One sample t-test results for the frequency of engagement in DfS practices

\begin{tabular}{|c|c|c|c|c|c|c|c|c|c|c|c|c|}
\hline \multirow{3}{*}{$\begin{array}{l}\text { DfS practice } \\
\text { code }\end{array}$} & \multirow[t]{3}{*}{$\mathrm{n}$} & \multirow[t]{3}{*}{ Mean } & \multirow{3}{*}{$\begin{array}{c}\text { Rank of } \\
\text { Mean }\end{array}$} & \multirow[t]{3}{*}{ Std. Dev. } & \multirow{3}{*}{$\begin{array}{c}\text { Std. } \\
\text { Error } \\
\text { Mean }\end{array}$} & \multicolumn{7}{|c|}{ Test Value $=3.5$} \\
\hline & & & & & & \multirow[t]{2}{*}{$\mathrm{t}$} & \multirow[t]{2}{*}{$\mathrm{df}$} & \multirow[t]{2}{*}{$p$ (2-tailed) } & \multirow[t]{2}{*}{$p$ (1-tailed) } & \multirow[t]{2}{*}{ Mean Difference } & \multicolumn{2}{|c|}{$\begin{array}{c}\text { 95\% Confidence } \\
\text { Interval }\end{array}$} \\
\hline & & & & & & & & & & & Lower & Uppe \\
\hline DfS-P.14 & 58 & 3.76 & 1 & 0.823 & 0.108 & 2.393 & 57 & 0.020 & 0.010 & 0.259 & 0.04 & 0.48 \\
\hline DfS-P.2 & 59 & 3.64 & 2 & 1.013 & 0.132 & 1.092 & 58 & 0.279 & 0.140 & 0.144 & -0.12 & 0.41 \\
\hline DfS-P.3 & 59 & 3.59 & 3 & 0.812 & 0.106 & 0.882 & 58 & 0.381 & 0.191 & 0.093 & -0.12 & 0.30 \\
\hline DfS-P.1 & 59 & 3.56 & 4 & 1.343 & 0.175 & 0.339 & 58 & 0.736 & 0.368 & 0.059 & -0.29 & 0.41 \\
\hline DfS-P.8 & 59 & 3.51 & 5 & 1.165 & 0.152 & 0.056 & 58 & 0.956 & 0.478 & 0.008 & -0.30 & 0.31 \\
\hline DfS-P.7 & 59 & 3.46 & 7 & 1.291 & 0.168 & -0.252 & 58 & 0.802 & 0.401 & -0.042 & -0.38 & 0.29 \\
\hline DfS-P.6 & 58 & 3.41 & 8 & 1.077 & 0.141 & -0.610 & 57 & 0.544 & 0.272 & -0.086 & -0.37 & 0.20 \\
\hline DfS-P.5 & 58 & 3.26 & 9 & 1.222 & 0.160 & -1.504 & 57 & 0.138 & 0.069 & -0.241 & -0.56 & 0.08 \\
\hline DfS-P.12 & 57 & 3.25 & 10 & 1.106 & 0.147 & -1.736 & 56 & 0.088 & 0.044 & -0.254 & -0.55 & 0.04 \\
\hline DfS-P.11 & 59 & 3.22 & 11 & 1.115 & 0.145 & -1.926 & 58 & 0.059 & 0.029 & -0.280 & -0.57 & 0.01 \\
\hline DfS-P.10 & 59 & 2.68 & 12 & 1.252 & 0.163 & -5.044 & 58 & 0.000 & 0.000 & -0.822 & -1.15 & -0.50 \\
\hline DfS-P.13 & 59 & 2.49 & 13 & 1.209 & 0.157 & -6.408 & 58 & 0.000 & 0.000 & -1.008 & -1.32 & -0.69 \\
\hline DfS-P.15 & 58 & 2.12 & 14 & 1.141 & 0.150 & -9.210 & 57 & 0.000 & 0.000 & -1.379 & -1.68 & -1.08 \\
\hline
\end{tabular}


Table 8: Independent samples t-test based on DfS awareness

\begin{tabular}{|c|c|c|c|c|c|c|c|c|c|c|c|c|}
\hline \multirow{3}{*}{$\begin{array}{l}\text { DfS practice } \\
\text { code }\end{array}$} & \multirow{3}{*}{$\begin{array}{c}\text { Awareness of } \\
\text { the DfS } \\
\text { concept }\end{array}$} & \multirow[t]{3}{*}{$\mathrm{n}$} & \multirow[t]{3}{*}{ Mean } & \multirow[t]{3}{*}{ Std. Dev. } & \multirow{3}{*}{$\begin{array}{l}\text { Std. Error } \\
\text { Mean }\end{array}$} & \multicolumn{7}{|c|}{ Independent samples $t$-test } \\
\hline & & & & & & \multirow[t]{2}{*}{$\mathrm{t}$} & \multirow[t]{2}{*}{$\mathrm{df}$} & \multirow[t]{2}{*}{$\begin{array}{l}p(2- \\
\text { tailed })\end{array}$} & \multirow[t]{2}{*}{$\begin{array}{c}\text { Mean } \\
\text { Difference }\end{array}$} & \multirow[t]{2}{*}{$\begin{array}{c}\text { Std. Error } \\
\text { Difference }\end{array}$} & \multicolumn{2}{|c|}{$\begin{array}{l}\text { 95\% Confidence } \\
\text { Interval }\end{array}$} \\
\hline & & & & & & & & & & & Lower & Upper \\
\hline \multirow[t]{2}{*}{ DfS-P.3 } & yes & 41 & 3.73 & 0.775 & 0.121 & 2.030 & 57 & 0.047 & 0.454 & 0.224 & 0.006 & 0.902 \\
\hline & no & 18 & 3.28 & 0.826 & 0.195 & & 30.728 & & & & & \\
\hline \multirow[t]{2}{*}{ DfS-P.4 } & yes & 42 & 3.81 & 1.042 & 0.161 & 3.568 & 57 & 0.001 & 1.104 & 0.309 & 0.484 & 1.723 \\
\hline & no & 17 & 2.71 & 1.160 & 0.281 & & 27.023 & & & & & \\
\hline \multirow[t]{2}{*}{ DfS-P.7 } & yes & 42 & 3.83 & 1.102 & 0.170 & 3.927 & 57 & 0.000 & 1.304 & 0.332 & 0.639 & 1.969 \\
\hline & no & 17 & 2.53 & 1.281 & 0.311 & & 26.124 & & & & & \\
\hline \multirow[t]{2}{*}{ DfS-P.10 } & yes & 42 & 2.88 & 1.329 & 0.205 & & 57 & & & & & \\
\hline & no & 17 & 2.18 & 0.883 & 0.214 & 2.376 & 44.273 & 0.022 & 0.704 & 0.296 & 0.107 & 1.302 \\
\hline \multirow[t]{2}{*}{ DfS-P.13 } & yes & 42 & 2.71 & 1.274 & 0.197 & & 57 & & & & & \\
\hline & no & 17 & 1.94 & 0.827 & 0.201 & 2.753 & 45.230 & 0.008 & 0.773 & 0.281 & 0.208 & 1.339 \\
\hline
\end{tabular}

Table 9: Independent samples t-test based on professional affiliation

\begin{tabular}{|c|c|c|c|c|c|c|c|c|c|c|c|c|}
\hline \multirow{3}{*}{$\begin{array}{l}\text { DfS practice } \\
\text { code }\end{array}$} & \multirow{3}{*}{$\begin{array}{l}\text { Professional } \\
\text { body } \\
\text { membership }\end{array}$} & \multirow[t]{3}{*}{$\mathrm{n}$} & \multirow[t]{3}{*}{ Mean } & \multirow{3}{*}{$\begin{array}{c}\text { Std. } \\
\text { Deviation }\end{array}$} & \multirow{3}{*}{$\begin{array}{l}\text { Std. } \\
\text { Error } \\
\text { Mean }\end{array}$} & \multicolumn{7}{|c|}{ Independent samples $t$-test } \\
\hline & & & & & & $\mathrm{t}$ & $\mathrm{df}$ & $\begin{array}{c}p(2- \\
\text { tailed })\end{array}$ & $\begin{array}{c}\text { Mean } \\
\text { Difference }\end{array}$ & $\begin{array}{l}\text { Std. Error } \\
\text { Difference }\end{array}$ & $\begin{array}{r}95 \% \mathrm{C} \\
\mathrm{Int}\end{array}$ & $\begin{array}{l}\text { fidence } \\
\text { val }\end{array}$ \\
\hline & & & & & & & & & & & Lower & Upper \\
\hline \multirow[t]{2}{*}{ DfS-P.15 } & yes & 52 & 2.00 & 1.085 & 0.150 & -2.477 & 56 & 0.016 & -1.167 & 0.471 & -2.110 & -0.223 \\
\hline & no & 6 & 3.17 & 1.169 & 0.477 & & 6.037 & & & & & \\
\hline
\end{tabular}


Table 10: Independent samples t-test based on DfS lessons

\begin{tabular}{|c|c|c|c|c|c|c|c|c|c|c|c|c|}
\hline \multirow{3}{*}{$\begin{array}{l}\text { DfS } \\
\text { practice } \\
\text { code }\end{array}$} & \multirow{3}{*}{$\begin{array}{c}\text { Receipt } \\
\text { of DfS } \\
\text { lessons }\end{array}$} & \multirow[t]{3}{*}{$\mathrm{n}$} & \multirow[t]{3}{*}{ Mean } & \multirow{3}{*}{$\begin{array}{c}\text { Std. } \\
\text { Deviation }\end{array}$} & \multirow{3}{*}{$\begin{array}{c}\text { Std. Error } \\
\text { Mean }\end{array}$} & \multicolumn{7}{|c|}{ Independent samples $t$-test } \\
\hline & & & & & & \multirow[t]{2}{*}{$\mathrm{t}$} & \multirow[t]{2}{*}{ df } & \multirow[t]{2}{*}{$p$ (2-tailed) } & \multirow[t]{2}{*}{$\begin{array}{c}\text { Mean } \\
\text { Difference }\end{array}$} & \multirow[t]{2}{*}{$\begin{array}{l}\text { Std. Error } \\
\text { Difference }\end{array}$} & \multicolumn{2}{|c|}{$\begin{array}{c}95 \% \text { Confidence } \\
\text { Interval }\end{array}$} \\
\hline & & & & & & & & & & & Lower & Upper \\
\hline \multirow[t]{2}{*}{ DfS-P.3 } & yes & 18 & 3.28 & 0.669 & 0.158 & -2.030 & 57 & 0.047 & -0.454 & 0.224 & -0.902 & -0.006 \\
\hline & no & 41 & 3.73 & 0.837 & 0.131 & & 40.315 & & & & & \\
\hline \multirow[t]{2}{*}{ DfS-P.4 } & yes & 17 & 4.00 & 0.707 & 0.171 & & 57 & & & & & \\
\hline & no & 42 & 3.29 & 1.274 & 0.197 & 2.738 & 51.191 & 0.008 & 0.714 & 0.261 & 0.191 & 1.238 \\
\hline \multirow[t]{2}{*}{ DfS-P.8 } & yes & 17 & 4.00 & 0.935 & 0.227 & 2.123 & 57 & 0.038 & 0.690 & 0.325 & 0.039 & 1.342 \\
\hline & no & 42 & 3.31 & 1.199 & 0.185 & & 37.839 & & & & & \\
\hline \multirow[t]{2}{*}{ DfS-P.9 } & yes & 17 & 2.24 & 1.091 & 0.265 & 2.568 & 57 & 0.013 & 0.592 & 0.231 & 0.131 & 1.054 \\
\hline & no & 42 & 1.64 & 0.656 & 0.101 & & 20.847 & & & & & \\
\hline \multirow[t]{2}{*}{ DfS-P. 15} & yes & 16 & 2.63 & 1.088 & 0.272 & 2.143 & 56 & 0.036 & 0.696 & 0.325 & 0.045 & 1.347 \\
\hline & no & 42 & 1.93 & 1.113 & 0.172 & & 27.735 & & & & & \\
\hline
\end{tabular}


For the ANOVA test based on professional role, the results in Table 11 show that a significant outcome was obtained for only one practice (i.e. DfS-P.12). For the ANOVA test based on the highest level of education no significant results were obtained. Regarding the comparison between the respondents based to their years of experience in role as designers, there was a significant outcome for only one practice (i.e. DfS-P.10) as shown in Table 12. Regarding the comparison based on size of organisation, there was a significant outcome for only two practices (i.e. DfS-P.9 and DfS-P.10) as shown by Table 13.

Table 11: One-Way ANOVA test based on the professional role

\begin{tabular}{lcccccc}
\hline \multirow{2}{*}{$\begin{array}{l}\text { DfS practice } \\
\text { code }\end{array}$} & Comparison & $\begin{array}{l}\text { Sum of } \\
\text { Squares }\end{array}$ & df & Mean Square & F & $p(2$-tailed) \\
\hline DfS-P.12 & Between Groups & 11.688 & 2 & 5.844 & 5.549 & 0.006 \\
\cline { 2 - 7 } & Within Groups & 56.874 & 54 & 1.053 & & \\
\cline { 2 - 6 } & Total & 68.561 & 56 & & \\
\hline
\end{tabular}

Table 12: One-Way ANOVA test based on the years of experience in the role

\begin{tabular}{lcccccc}
\hline \multirow{2}{*}{$\begin{array}{l}\text { DfS practice } \\
\text { code }\end{array}$} & Comparison & $\begin{array}{l}\text { Sum of } \\
\text { Squares }\end{array}$ & $\mathrm{df}$ & Mean Square & $\mathrm{F}$ & $p(2$-tailed) \\
\hline DfS-P.10 & Between Groups & 41.482 & 17 & 2.440 & 2.164 & 0.025 \\
\cline { 2 - 7 } & Within Groups & 41.718 & 37 & 1.128 & & \\
\cline { 2 - 7 } & Total & 83.200 & 54 & & \\
\hline
\end{tabular}

Table 13: One-Way ANOVA test based on the size of the organisation

\begin{tabular}{|c|c|c|c|c|c|c|}
\hline DfS practice code & Comparison & $\begin{array}{l}\text { Sum of } \\
\text { Squares }\end{array}$ & $\mathrm{df}$ & Mean Square & $\mathrm{F}$ & $p$ (2-tailed) \\
\hline \multirow[t]{3}{*}{ DfS-P.9 } & Between Groups & 5.815 & 3 & 1.938 & 2.988 & 0.039 \\
\hline & Within Groups & 33.738 & 52 & 0.649 & & \\
\hline & Total & 39.554 & 55 & & & \\
\hline \multirow[t]{3}{*}{ DfS-P.10 } & Between Groups & 12.850 & 3 & 4.283 & 3.196 & 0.031 \\
\hline & Within Groups & 69.703 & 52 & 1.340 & & \\
\hline & Total & 82.554 & 55 & & & \\
\hline
\end{tabular}

\section{Discussion}

The results from the data analyses offer a valuable insight regarding the status of the concept of DfS in Palestine. These results also provide indications about DfS characteristics and the factors which affect its implementation in Palestine.

The low frequency of engagement in DfS practices as presented by the one sample $t$-test (in Table 7) align with the findings of previous OSH studies as well as governmental reports on Palestine. The previous studies and reports agree on the poor OSH performance and the high rate of construction fatalities in the Palestinian construction industry. The high rate of construction fatalities in Palestine gives a general indication of weak implementation of OSH management on projects which ought to include DfS implementation. Furthermore, the low frequency of implementing DfS practices in Palestine, which is considered as a developing 
country, is in line with the findings by Manu et al. (2018a; 2019) who reported a low DfS implementation among architects in other developing countries (i.e. Ghana and Nigeria). Collectively, these results begin to give a picture of limited implementation of DfS in developing countries.

In general, the results of the DfS awareness (shown in Table 4) and DfS attitude (shown in Figure 4 and Table 3) revealed a very high level of awareness and positive attitude towards the concept of DfS among the respondents. Despite the high awareness and positive attitude, the frequency of implementing DfS practices (shown by Table 6) and the one sample $t$-test results (shown by Table 7), reflect a poor implementation of DfS practices. While many studies have suggested the designer's awareness and attitude towards the concept of DfS are important factors that affect the level of DfS implementation (Hinze and Wiegand, 1992; Gambatese et al., 2005a), the results of this study do not mirror this. This discord between the designers' awareness and attitude with the level of DfS implementation does not necessarily imply that designers' awareness and attitude in Palestine are not important factors. However, this indicates that a high level of awareness and positive attitude may not necessarily or solely drive a high level of DfS implementation as was also found by Goh and Chua (2016) and Manu et al. (2018a; 2019). The discord can also be an indication of the absence of other key factors which affect the implementation of DfS. These factors could include the designers' knowledge and education concerning the concept of DfS (Weinstein et al., 2005; Behm, 2008). In this regard, the survey results (shown in Table 4.2) suggested a lack of DfS courses in the architecture and engineering curricula (i.e. $70 \%$ of the respondents have not received any lessons about DfS during their formal education). Therefore, the limited DfS knowledge and education could be a factor that impedes DfS implementation in Palestine.

While it was expected that there would be significant differences in the level of implementation of the concept of DfS between various groups, the independent samples $t$-tests showed unexpected results. The expectations held based on previous studies were that:

1. The frequency of implementing DfS practices by participants who have received DfS lessons would be significantly higher than those who have not.

2. The frequency of implementing DfS practices by participants who have received DfS training would be significantly higher than those who have not.

3. The frequency of implementing DfS practices by participants who are aware of DfS would be significantly higher than those who are not.

4. The frequency of implementing DfS practices by participants who are affiliated to a professional body would be significantly higher than those who are not.

The first three expectations are based on previous research which underline the effect of DfS awareness, education and training on DfS implementation (Hinze and Wiegand, 1992; Gambatese and Hinze, 1999; Gambatese et al., 2005a). The other expectation is based on the logic that design professional associations support best practices that should include DfS (Manu et al., 2018a; 2019).

Similar to the independent samples t-tests, the results of the one-way ANOVA tests are out of sync with previous research. The expectations held based on previous research were that:

1. The frequency of implementing DfS practices would be significantly different based on designers' level of education.

2. The frequency of implementing DfS practices would be significantly different based on designers' experience. 
3. The frequency of implementing DfS practices would be significantly different based on designers' size of organisation.

The first expectation is based on the literature that emphasised the importance of education in implementing DfS (Gambatese et al., 2005a). The second expectation is based on the rationale that designers with more experience have more implicit knowledge of safety and construction, and thus would be more engaged in DfS practices than other designers with fewer years of experience (Öney-Yazıc1 and Dulaimi, 2015). Finally, the third expectation is based on the literature, which indicates that bigger firms are more concerned with safety management issues than smaller firms (Goh and Chua, 2016; Manu et al., 2018b).

Overall, the outcomes of the independent samples $t$-tests and one-way ANOVA tests suggest that DfS awareness, education and training, professional body membership, experience in role, and organisation size have very limited association with the frequency of implementing DfS practices among the design professionals in Palestine. While the results do not necessarily indicate that these factors have no effect on DfS implementation, the results, however, suggests the presence of barriers/challenges that may be undermining DfS implementation in Palestine. The existence of these barriers in Palestine is also reflected in Figure 6 where over half of the respondents (i.e. 58\%) indicated that the Palestinian construction industry is not ready yet to take on the responsibilities of DfS.

Although the respondents have shown a very high interest in receiving DfS training (i.e. 90\% of the respondents), very low engagement in DfS training was revealed (i.e. $18 \%$ of the respondents). This can be attributed to potential DfS knowledge acquisition barriers, as suggested by Manu et al. (2019). These barriers could include the inadequacy or unavailability of DfS training programmes or other individual or organisational related challenges (e.g. lack of organisational commitment or support for DfS related training for design staff) (Manu et al., 2019).

\section{Conclusions}

This research investigated DfS implementation among design professionals in the Palestinian construction industry. The main conclusions drawn from the research are that:

- The level of engagement in DfS practices among designers is very low despite a high DfS awareness and positive attitude towards DfS.

- The level of designers' engagement in DfS training is very low although there is high interest amongst designers in undertaking DfS training.

- There seem to be inadequate coverage of DfS in the formal education of designers.

- DfS awareness, DfS education and training, designers' professional affiliation, experience, level of education, and size of work organisation appears to have limited association with the level of engagement in DfS practices.

- Notwithstanding the above, the provision DfS education, provision of DfS related computer tools, DfS professional development training, emphasis on DfS by client, emphasis on DfS by government, and availability of DfS related industry standards, codes or guides, are perceived by designers to have a high influence of DfS implementation.

- There seem to be a dominant view among designers that the Palestian construction industry is not ready for DfS implementation, and this view is indicative of the presence of barriers/challenges which are undermining DfS implementation. 


\subsection{Implications for Practice}

The insights provided by this study present an opportunity for the construction industry to improve the implementation of DfS by considering the following recommendations:

- The low engagement in DfS practices in Palestine prevents the construction industry from realising the benefits of implementing this concept. Overall, collaborative efforts are therefore required by construction industry stakeholders, including design professionals, clients, professional bodies, educational institutions and legislators/regulators to promote and improve the implementation of DfS in Palestine.

- Educational institutions offering built environment architectural and engineering courses should seek to incorporate DfS education into their syllabus.

- The high interest in undertaking DfS training among designers presents a good opportunity for the design professional bodies and other industry associations to develop and deliver DfS professional development training courses while taking into account the designers' preferred methods of engaging in DfS training.

- The study revealed that the availability of DfS computer tools can be a useful stimulus for DfS implementation. While several DfS computer tools are available (see Poghosyan et al., 2018), the use of such tools is likely to be low given the low engagement in DfS practices reported by the study. Therefore, aspects of DfS education and training could incorporate raising awareness as well as the use of such tools.

- Clients, including the government as a major construction procurer, should promote DfS by encouraging and supporting its practise on projects. From the perspective of the government, while the possibility of introduction of DfS related legislation should be considered, such initiative would have to be backed by adequate enforcement, which tends to be lax in developing countries (see Umeokafor et al., 2014).

- DfS implementation in construction has been prominent in some countries for several years (e.g. countries in the EU). In view of this, there is the opportunity of drawing lessons from DfS implementation and its evolution over the years in those countries and then consider the possibility to appropriately contextualise some of those lessens into the context of Palestine.

\subsection{Study's Limitations and Implications for Research}

This study has the following limitations:

- Different social, political and economic situations exist between the two regions of Palestine: the West Bank; and the Gaza Strip (Barakat et al., 2019). This study focused on the West Bank region, and thus the findings may not reflect the situation in the Gaza Strip. Therefore, further studies need to be undertaken in the Gaza strip to enrich the insights offered by this study.

- The results of this study align with those of similar studies in other developing countries (Manu et al., 2018a, 2019) and therefore collectively the findings begin to portray a pattern of the presence of certain barriers/challenges that may be undermining DfS implementation in developing countries. In line with this, additional studies on DfS implementation in developing countries are needed in order to develop an understanding of what such barriers might be. 


\section{References}

Abdelhamid, T.S., Everett, J.G., 2000. Identifying root causes of construction accidents. J. Constr. Eng. Manag. 126, 52-60. https://doi.org/10.1061/(ASCE)07339364(2000)126:1(52)

Abu-Arra, M.Z., Al-Turk, L., 2014. Work injuries and compensation in Palestine. Available online at http://dwrc.org/attachment/141/در اسة حول إصابات العمل و التعويضات عنها.pdf [Accessed 29/06/19].

Al-Jubeh, A.I., Ziara, M.M., 2012. Assessment of the construction industry practice in Palestine based on the design for construction safety (DFCS) concept, in: Islamic University of Gaza Faculty of Engineering, The 4th International Engineering Conference -Towards Engineering of 21st Century.

Al-Sari', M.I., Al-Khatib, I.A., 2012. Workers' safety in the construction industry in the southern West Bank of Palestine. East. Mediterr. Heal. J. 18, 1028-1033.

Arab Monetary Fund (AMF), 2017. The Joint Arab Economic Report, 2017. Available online at https://www.amf.org.ae/ar/content/2017-التقرير_الاقتصادي_العربي_الموحد [Accessed 11/07/19].

Atkinson, A.R., Westall, R., 2010. The relationship between integrated design and construction and safety on construction projects. Constr. Manag. Econ. 28, 1007-1017. https://doi.org/10.1080/01446193.2010.504214

Barakat, S., Milton, S., Elkahlout, G., 2019. Reconstruction under siege: the Gaza Strip since 2007. Disasters 1-25. https://doi.org/10.1111/disa.12394

Behm, M., 2005. Linking construction fatalities to the design for construction safety concept. Saf. Sci. 43, 589-611. https://doi.org/10.1016/j.ssci.2005.04.002

Behm, M., 2006. An analysis of construction accidents from a design perspective.

Behm, M., 2008. Construction sector. J. Saf. Res. 39, 175-178. https://doi.org/10.1016/j.jsr.2008.02.007

Behm, M., Culvenor, J., Dixon, G., 2014. Development of safe design thinking among engineering students. Saf. Sci. 63, 1-7. https://doi.org/10.1016/j.ssci.2013.10.018

Bryman, A., 2012. Social research methods, 4th ed. ed. Oxford University Press Inc., New York.

Bureau of Labor Statistics, 2018. Fatal occupational injuries counts and rates by selected industries, 2016-17. Available online at https://www.bls.gov/news.release/cfoi.t04.htm [Accessed 21/07/19].

Christianson, C.R., 2005. Design for construction safety: a case study with architect's perceptions. Oregon State University. 
Cooke, T., Lingard, H., 2011. A retrospective analysis of work-related deaths in the Australian construction, in: Proceedings of the ARCOM Twenty-Seventh Annual Conference. pp. 279-288.

Creswell, J.W., 2014. Research design: qualitative, quantitative, and mixed methods approaches, 4th ed. ed. SAGE Publications, Thousand Oaks.

Data USA, 2019. Construction. Available online at https://datausa.io/profile/naics/construction-sub-sector [Accessed 21/07/19].

Department of Labor and Training, 2019. United States labor force statistics. Available online at http://www.dlt.ri.gov/lmi/laus/us/usadj.htm [Accessed 21/07/19].

Department of Occupational Health and Safety, 2015. Occupational accidents statistics by sector until December 2015. Available online at http://www.dosh.gov.my/index.php/en/archive-statistics/2015/1713-occupationalaccidents-statistics-by-sector-until-december-2015 [Accessed 12/07/19].

Engineers Association in the West Bank, 2019. Directory of engineering offices and companies. Available online at https://www.paleng.org/?p=859 [Accessed 6/06/19].

Enshass, A., Aqaad, M., 2011. Assessing the level of the safety practice in construction companies in Palestine. Islam. Univ. J. (Series Nat. Stud. Eng.) 19, 87-102.

Enshass, A., Choudhry, R.M., Aqaad, M., 2013. Identifing causes of safety degradation in construction projects in Palestine. Int. J. Constr. Proj. Manag. 5, 3-30.

Enshassi, A., 1997. Construction safety issues in Gaza Strip: A survey of the causes of accidents on building sites, the current safety procedures used by local contractors and recommendations for improved safety. Build. Res. Inf. 25, 370-373. https://doi.org/10.1080/096132197370192

Enshassi, A. A., Mayer, P. E., Choudhry, R. M., Hassouna, A. M., 2007. Perception of contracting parties on construction safety in the Gaza Strip, Palestine. Arab Gulf J. Sci. Res. 25, 120-129.

Enshassi, A., Abu Zaiter, M., 2014. Implementation of lean tools on safety in construction projects in Palestine, in: 22nd Annual Conference of the International Group for Lean Construction. Oslo, Norway, pp. 1205-1218.

Enshassi, A., Ayyash, A., Choudhry, R.M., 2016. BIM for construction safety improvement in Gaza strip: awareness, applications and barriers. Int. J. Constr. Manag. 16, 249-265. https://doi.org/10.1080/15623599.2016.1167367

Enshassi, A., Choudhry, R.M., Mayer, P.E., Shoman, Y., 2008. Safety performance of subcontractors in the Palestinian construction industry'. J. Constr. Dev. Ctries. 13, 5162 .

Enshassi, A., El-Moghany, S., Mayer, P.E., Zimmermann, J., 2011. Material wastage on construction sites in the Gaza Strip. Int. J. Constr. Proj. Manag. 3, 107-125. 
Enshassi, A., Mohamed, S., Abushaban, S., 2009. Factors affecting the performance of construction projects in the Gaza Strip. J. Civ. Eng. Manag. 15, 269-280. https://doi.org/10.3846/1392-3730.2009.15.269-280

Enshassi, A., Mohamed, S., Modough, Z., 2013. Contractors' selection criteria: Opinions of Palestinian construction professionals. Int. J. Constr. Manag. 13, 19-37. https://doi.org/10.1080/15623599.2013.10773203

Enshassi, A.A., Mayer, P.E., 2007. Perception of contracing parties on construction safety in the Gaza Strip, Palestine. Arab Gulf J. Sci. Res. 25, 120-129.

Fanack, 2017. Palestinian economic sectors. Available online at https://fanack.com/palestine/economy/palestinian-economic-sectors/ [Accessed 12/07/19].

Field, A., 2013. Discovering statistics using IBM SPSS statistics: and sex and drugs and rock 'n' roll, 4th ed. ed. SAGE Publications, London.

Gambatese, J., Hinze, J., 1999. Addressing construction worker safety in the design phase: designing for construction worker safety. Autom. Constr. 8, 643-649. https://doi.org/10.1016/S0926-5805(98)00109-5

Gambatese, J.A., 2000. Safety constructability: Designer involvement in construction site safety, in: Proceedings of Construction Congress VI: Building Together for a Better Tomorrow in an Increasingly Complex World. pp. 650-660. https://doi.org/10.1061/40475(278)70

Gambatese, J.A., Behm, M., Hinze, J.W., 2005a. Viability of designing for construction worker safety. J. Constr. Eng. Manag. 131, 1029-1036. https://doi.org/10.1061/(ASCE)0733-9364(2005)131:9(1029)

Gambatese, J.A., Hinze, J., Behm, M., 2005b. Investigation of the viability of designing for safety.

Gambatese, J.A., Hinze, J.W., Haas, C.T., 1997. Tool to design for construction worker safety. J. Archit. Eng. 3, 32-41. https://doi.org/10.1061/(ASCE)1076-0431(1997)3:1(32)

Gangolells, M., Casals, M., Forcada, N., Roca, X., Fuertes, A., 2010. Mitigating construction safety risks using prevention through design. J. Safety Res. 41, 107-122. https://doi.org/10.1016/j.jsr.2009.10.007

Gibb, A., Haslam, R., Gyi, D., Hide, S., Duff, R., 2006. What causes accidents?, in: Proceedings of the Institution of Civil Engineers - Civil Engineering. Thomas Telford Ltd , pp. 46-50. https://doi.org/10.1680/cien.2006.159.6.46

Global Construction Perspectives and Oxford Economics, 2015. Global Construction 2030. Global Construction Perspectives and Oxford Economics, London (UK).

Goh, Y.M., Chua, S., 2016. Knowledge, attitude and practices for design for safety: A study on civil \& structural engineers. Accid. Anal. Prev. 93, 260-266. https://doi.org/10.1016/j.aap.2015.09.023 
Haslam, R.A., Hide, S.A., Gibb, A.G.F., Gyi, D.E., Pavitt, T., Atkinson, S., Duff, A.R., 2005. Contributing factors in construction accidents. Appl. Ergon. 36, 401-415. https://doi.org/10.1016/j.apergo.2004.12.002

Hayne, G., Kumar, B., Hare, B., 2017. Design hazard identification and the link to site experience. Proc. Inst. Civ. Eng. - Manag. Procure. Law 170, 85-94. https://doi.org/10.1680/jmapl.16.00014

Health and Safety Executive, 2015. Managing health and safety in construction: Construction (Design and Management) Regulations 2015-Guidance on Regulations L153. HSE Books, Norwich.

Health and Safety Executive, 2018a. Construction statistics in Great Britain, 2018. Available online at http://www.hse.gov.uk/statistics/industry/construction.pdf [Accessed 5/06/19].

Health and Safety Executive, 2018b. Costs to Britain of workplace fatalities and self-reported injuries and ill health, 2016/17. Available online at http://www.hse.gov.uk/statistics/pdf/cost-to-britain.pdf [Accessed 20/07/19].

Health and Safety Executive, 2019. Workplace fatal injuries in Great Britain, 2019. Available online at http://www.hse.gov.uk/statistics/pdf/fatalinjuries.pdf [Accessed 23/06/19].

Hendrickson, C., 2008. Project Management for Construction: Fundamental Concepts for Owners, Engineers, Architects and Builders. Worldwide Web Publication, Pittsburgh.

Hinze, J., Wiegand, F., 1992. Role of designers in construction worker safety. J. Constr. Eng. Manag. 118, 677-684. https://doi.org/10.1061/(ASCE)0733-9364(1992)118:4(677)

Huang, X., Hinze, J., 2006. Owner's role in construction safety. J. Constr. Eng. Manag. 132, 164-173. https://doi.org/10.1061/(ASCE)0733-9364(2006)132:2(164)

Karakhan, A.A., 2016. Designer's liability: Why applying PTD principles is necessary. Prof. Saf. 61, 53-58.

Korman, R., 2001. Wanted: New idea: Panel ponders ways to end accidents and health hazards. Eng. News-Record 26-29.

Ling, F.Y.Y., Liu, M., Woo, Y.C., 2009. Construction fatalities in Singapore. Int. J. Proj. Manag. 27, 717-726. https://doi.org/10.1016/j.ijproman.2008.11.002

López-Arquillos, A., Rubio-Romero, J.C., Martinez-Aires, M.D., 2015. Prevention through Design (PtD). The importance of the concept in Engineering and Architecture university courses. Saf. Sci. 73, 8-14. https://doi.org/10.1016/j.ssci.2014.11.006

Mahamid, I., 2012. Factors affecting contractor's business failure: Contractors' perspective. Eng. Constr. Archit. Manag. 19, 269-285. https://doi.org/10.1108/09699981211219607

Manu, P., Ankrah, N., Proverbs, D., Suresh, S., 2010. An approach for determining the extent of contribution of construction project features to accident causation. Saf. Sci. 48, 687692. https://doi.org/10.1016/j.ssci.2010.03.001 
Manu, P., Ankrah, N., Proverbs, D., Suresh, S., 2014. The health and safety impact of construction project features. Eng. Constr. Archit. Manag. 21, 65-93. https://doi.org/10.1108/ECAM-07-2012-0070

Manu, P., Poghosyan, A., Agyei, G., Mahamadu, A.-M., Dziekonski, K., 2018a. Design for safety in construction in sub-Saharan Africa: a study of architects in Ghana. Int. J. Constr. Manag. 1-13. https://doi.org/10.1080/15623599.2018.1541704

Manu, P., Mahamadu, A.M., Phung, V.M., Nguyen, T.T., Ath, C., Heng, A.Y.T., Kit, S.C., 2018b. Health and safety management practices of contractors in South East Asia: A multi country study of Cambodia, Vietnam, and Malaysia. Saf. Sci. 107, 188-201. https://doi.org/10.1016/j.ssci.2017.07.007

Manu, P., Poghosyan, A., Mshelia, I.M., Iwo, S.T., Mahamadu, A.M., Dziekonski, K., 2019. Design for occupational safety and health of workers in construction in developing countries: a study of architects in Nigeria. Int. J. Occup. Saf. Ergon. 25, 99-109. https://doi.org/10.1080/10803548.2018.1485992

Martínez Aires, M.D., Rubio Gámez, M.C., Gibb, A., 2010. Prevention through design: The effect of European Directives on construction workplace accidents. Saf. Sci. 48, 248 258. https://doi.org/10.1016/j.ssci.2009.09.004

Martínez-Aires, M.D., Rubio Gámez, M.C., Gibb, A., 2016. The impact of occupational health and safety regulations on prevention through design in construction projects: Perspectives from Spain and the United Kingdom. Work A J. Prev. Assess. Rehabil. 53, 181-191. https://doi.org/10.3233/WOR-152148

Ministry of Manpower, 2015. A healthy workforce in a safe workplace - Annual Report 2015. Available online at http://www.mom.gov.sg/ebook/oshdar2015/pdf/OSHD_AR2016_LoRes.pdf. [Accessed 12/07/19].

Morrow, S., Hare, B., Cameron, I., 2016. Design engineers' perception of health and safety and its impact in the design process. Eng. Constr. Archit. Manag. 23, 40-59. https://doi.org/10.1108/ECAM-01-2013-0009

Naoum, S.G., 2013. Dissertation research \&amp; writing for construction students., 3rd ed. ed. Routledge, New York.

Office of National Statistics, 2018. Construction statistics: Number 19. Office of National Statistics

Öney-Yazıc1, E., Dulaimi, M.F., 2015. Understanding designing for construction safety: the interaction between confidence and attitude of designers and safety culture. Archit. Eng. Des. Manag. 11, 325-337. https://doi.org/10.1080/17452007.2014.895697

Palestinian Central Bureau of Statistics (PCBS), 2011. The performance of the Palestinian economy, 2010. Available online at http://www.pcbs.gov.ps/Portals/_PCBS/Downloads/book1756.pdf [Accessed 10/07/19].

Palestinian Central Bureau of Statistics (PCBS), 2019. Estimated population in Palestine by governorate, 1997-2021. Available online at 
http://www.pcbs.gov.ps/Portals/_Rainbow/Documents/2010-97 المحافظات عربي.html [Accessed 15/07/19].

Poghosyan, A., Manu, P., Mahamadu, A.M., Akinade, O., Mahdjoubi, L., Gibb, A., Behm, M., 2020. A web-based design for occupational safety and health capability maturity indicator. Saf. Sci. 122, 104516. https://doi.org/10.1016/j.ssci.2019.104516

Poghosyan, A., Manu, P., Mahdjoubi, L., Gibb, A.G.F., Behm, M., Mahamadu, A.M., 2018. Design for safety implementation factors: a literature review. J. Eng. Des. Technol. 16, 783-797. https://doi.org/10.1108/JEDT-09-2017-0088

Rodrigues, F., Coutinho, A., Cardoso. C., 2015. Correlation of causal factors that influence construction safety performance: a model. Work A J. Prev. Assess. Rehabil. 51, 721730. https://doi.org/10.3233/WOR-152030

Sacks, R., Whyte, J., Swissa, D., Raviv, G., Zhou, W., Shapira, A., 2015. Safety by design: dialogues between designers and builders using virtual reality. Constr. Manag. Econ. 33, 55-72. https://doi.org/10.1080/01446193.2015.1029504

Sadeghi, L., Mathieu, L., Tricot, N., Al Bassit, L., 2015. Developing a safety indicator to measure the safety level during design for safety. Saf. Sci. 80, 252-263. https://doi.org/10.1016/j.ssci.2015.08.006

Saunders, M., Lewis, P. and Thornhill, A., 2016. Research methods for business students, 7th ed. ed. Pearson Education Limited, Harlow.

Sawa, 2018. Labor: $73 \%$ of fatal work injuries, mostly in the construction sector. Available online at https://palsawa.com/post/143631/العمل-73-من-إصابات_العمل_القاتلة_معظمها_في_قطاع-Averien [البناء [Accessed 17/06/19].

Schulte, P.A., Rinehart, R., Okun, A., Geraci, C.L., Heidel, D.S., 2008. National Prevention through Design (PtD) Initiative. J. Safety Res. 39, 115-121. https://doi.org/10.1016/j.jsr.2008.02.021

Suraji, A., Duff, A.R., Peckitt, S.J., 2001. Development of causal model of construction accident causation. J. Constr. Eng. Manag. 127, 337-344. https://doi.org/10.1061/(ASCE)0733-9364(2001)127:4(337)

Szymberski, R.T., 1997. Construction project safety planning. TAPPI J. 80, 69-74.

Takala, J., Hämäläinen, Päivi, Saarela, K.L., Yun, L.Y., Manickam, K., Jin, T.W., Heng, P., Tjong, C., Kheng, L.G., Lim, S., Lin, G.S., 2014. Global estimates of the burden of injury and illness at work in 2012. J. Occup. Environ. Hyg. 11, 326-337. https://doi.org/10.1080/15459624.2013.863131

Toh, Y.Z., Goh, Y.M., Guo, B.H.W., 2017. Knowledge, attitude, and practice of design for safety: Multiple stakeholders in the Singapore construction industry. J. Constr. Eng. Manag. 143, 04016131. https://doi.org/10.1061/(ASCE)CO.1943-7862.0001279

Toole, T.M., 2005. Increasing engineers' role in construction safety: Opportunities and barriers. J. Prof. Issues Eng. Educ. Pract. 131, 199-207. https://doi.org/10.1061/(ASCE)1052-3928(2005)131:3(199) 
Toole, T.M., Gambatese, J., 2008. The trajectories of prevention through design in construction. J. Safety Res. 39, 225-230. https://doi.org/10.1016/j.jsr.2008.02.026

Toole, T.M., Gambatese, J.A., Abowitz, D.A., 2017. Owners' role in facilitating prevention through design. J. Prof. Issues Eng. Educ. Pract. 143, 04016012. https://doi.org/10.1061/(ASCE)EI.1943-5541.0000295

Toole, T.M., Heckel, P., Hallowell, M., 2013. Policy development: A key factor in promoting PTD. Prof. Saf. 58, 41-47.

Tymvios, N., Gambatese, J.A., 2016a. Perceptions about design for construction worker safety: Viewpoints from contractors, designers, and university facility owners. J. Constr. Eng. Manag. 142, 04015078. https://doi.org/10.1061/(ASCE)CO.1943-7862.0001067

Tymvios, N., Gambatese, J.A., 2016b. Direction for generating interest for design for construction worker safety-A delphi study. J. Constr. Eng. Manag. 142, 04016024. https://doi.org/10.1061/(ASCE)CO.1943-7862.0001134

Umeokafor N., Isaac, D., Jones, K., Umeadi, B., 2014. Enforcement of occupational safety and health regulations in Nigeria: an exploration. Eur. Sci. J. 3, 93-104.

United Nations, 2018. World economic situation and prospects 2018. Available online at https://www.un.org/development/desa/dpad/wpcontent/uploads/sites/45/publication/WESP2018_Full_Web-1.pdf [Accessed 10/06/19].

Votano, S., Sunindijo, R.Y., 2014. Client safety roles in small and medium construction projects in Australia. J. Constr. Eng. Manag. 140, 1-6. https://doi.org/10.1061/(ASCE)CO.1943-7862.0000899

Weinstein, M., Gambatese, J., Hecker, S., 2005. Can design improve construction safety?: Assessing the impact of a collaborative safety-in-design process. J. Constr. Eng. Manag. 131, 1125-1134. https://doi.org/10.1061/(ASCE)0733-9364(2005)131:10(1125)

World Bank, 2019. World Bank country and lending groups. Available online at https://datahelpdesk.worldbank.org/knowledgebase/articles/906519-world-bankcountry-and-lending-groups [Accessed 10/06/19].

World Population Review, 2019a. Ghana Population 2019. Available online at http://worldpopulationreview.com/countries/ghana-population/ [Accessed 25/072019].

World Population Review, 2019b. Nigeria Population 2019. Available online at http://worldpopulationreview.com/countries/nigeria-population/ [Accessed 25/07/2019].

Zhang, S., Teizer, J., Lee, J.K., Eastman, C.M., Venugopal, M., 2013. Building Information Modeling (BIM) and safety: Automatic safety checking of construction models and schedules. Autom. Constr. 29, 183-195. https://doi.org/10.1016/j.autcon.2012.05.006 